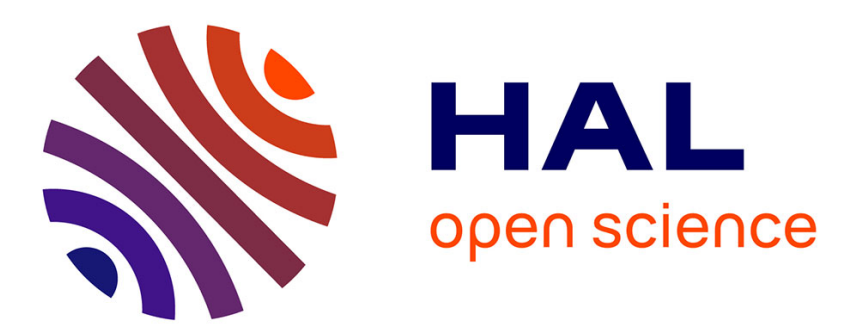

\title{
Biofilms in hospital effluents as a potential crossroads for carbapenemase-encoding strains
}

\author{
J. Ory, G. Bricheux, F. Robin, Anne Togola, C. Forestier, O. Traore
}

\section{To cite this version:}

J. Ory, G. Bricheux, F. Robin, Anne Togola, C. Forestier, et al.. Biofilms in hospital effluents as a potential crossroads for carbapenemase-encoding strains. Science of the Total Environment, 2019, 657, pp.7-15. 10.1016/j.scitotenv.2018.11.427 . hal-01948443

\section{HAL Id: hal-01948443 \\ https://hal.uca.fr/hal-01948443}

Submitted on 16 Oct 2019

HAL is a multi-disciplinary open access archive for the deposit and dissemination of scientific research documents, whether they are published or not. The documents may come from teaching and research institutions in France or abroad, or from public or private research centers.
L'archive ouverte pluridisciplinaire HAL, est destinée au dépôt et à la diffusion de documents scientifiques de niveau recherche, publiés ou non, émanant des établissements d'enseignement et de recherche français ou étrangers, des laboratoires publics ou privés. 


\section{Accepted Manuscript}

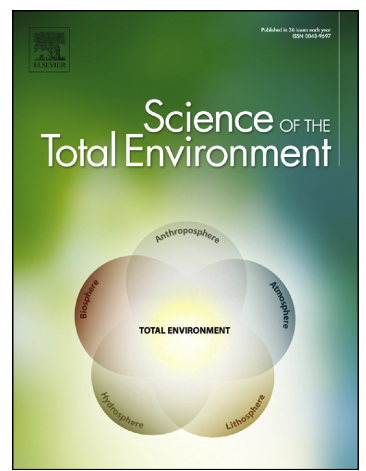

J. Ory, G. Bricheux, F. Robin, A. Togola, C. Forestier, O. Traore

PII:

S0048-9697(18)34782-X

DOI: https://doi.org/10.1016/j.scitotenv.2018.11.427

Reference:

STOTEN 29776

To appear in:

Science of the Total Environment

Received date:

6 September 2018

Revised date:

9 November 2018

Accepted date:

28 November 2018

Please cite this article as: J. Ory, G. Bricheux, F. Robin, A. Togola, C. Forestier, O. Traore , Biofilms in hospital effluents as a potential crossroads for carbapenemase-encoding strains. Stoten (2018), https://doi.org/10.1016/j.scitotenv.2018.11.427

This is a PDF file of an unedited manuscript that has been accepted for publication. As a service to our customers we are providing this early version of the manuscript. The manuscript will undergo copyediting, typesetting, and review of the resulting proof before it is published in its final form. Please note that during the production process errors may be discovered which could affect the content, and all legal disclaimers that apply to the journal pertain. 
Biofilms in hospital effluents as a potential crossroads for carbapenemase-encoding strains

$$
\text { J. Ory }{ }^{1,2} \text {, G. Bricheux }{ }^{1} \text {, F. Robin }{ }^{3,4} \text {, A. Togola }{ }^{5} \text {, C. Forestier }{ }^{1} \text {, O. Traore }{ }^{1,2}
$$

(1) Université Clermont Auvergne, CNRS, Laboratoire "Microorganismes : Génome et Environnement", F-63000 Clermont-Ferrand, France

(2) Service d'hygiène hospitalière, CHU de Clermont-Ferrand, Clermont-Ferrand, France

(3) Laboratoire de Bactériologie \& CNR de la Résistance aux Antibiotiques, CHU de ClermontFerrand, Clermont-Ferrand, France

(4) Université Clermont Auvergne, Inserm, M2ISH, F-63000, Clermont-Ferrand

(5) Bureau de recherches géologiques et minières (BRGM), 3 avenue Claude Guillemin, F45100, Orléans, France.

\section{Highlights:}

Bacteria harboring carbapenemase-encoding genes in hospital wastewater biofilms These genes are carried by conjugative plasmids

Carbapenem in effluent and bacterial resistance are potential hazards 


\section{$\underline{\text { Abstract }}$}

Bacterial resistance to carbapenem, which is mainly due to the successful dissemination of carbapenemase-encoding genes, has become a major health problem. Few studies have aimed to characterize the level of resistance in the environment, notably in hospital wastewater, which is a likely hotspot for exchange of antibiotic resistance genes.

In this work, we looked for the presence of imipenem-resistant bacteria and imipenem in the effluent of the teaching hospital of Clermont-Ferrand, France. Selective growth of bacteria from 14-day old biofilms formed in the pipe sewer showed that $22.1 \%$ of the isolates were imipenemresistant and identified as Aeromonas $(\mathrm{n}=23)$, Pseudomonas $(\mathrm{n}=10)$, Stenotrophomonas $(\mathrm{n}=4)$ and Acinetobacter $(\mathrm{n}=1)$. Fifteen of these strains harbored acquired carbapenemase-encoding genes $\operatorname{bla}_{\mathrm{VIM}}(\mathrm{n}=11), \operatorname{bla}_{\mathrm{OXA}-48}(\mathrm{n}=2), \operatorname{bla}_{\mathrm{GES}}(\mathrm{n}=1), \operatorname{bla}_{\mathrm{NDM}}(\mathrm{n}=1)$. All isolates also harbored associated resistances to aminoglycosides, fluoroquinolones and/or tetracyclin. S1-nuclease pulsed-field gel electrophoresis analysis of eight selected isolates showed that four of them harbored one to two plasmids of molecular weight between $48.5 \mathrm{~Kb}$ and $194 \mathrm{~Kb}$. In vitro transformation assays evidenced the presence of $b l a_{\mathrm{VIM}}$ and $b l a_{\mathrm{NDM}}$ on plasmids with the $b l a_{V I M}$ harboring $80 \mathrm{~Kb}$ plasmid having conjugative capacity.

The predicted environmental concentration of imipenem in the hospital effluent was $3.16 \mu \mathrm{g} / \mathrm{L}$, suggesting that biofilm bacteria are subjected to sub-MICs of imipenem within the effluent. However, no imipenem molecule was detected in the hospital effluent, probably owing to its instability: in vitro assays indicated that imipenem's biological activity was no longer detectable after $45 \mathrm{~h}$ of storage. However, the predictive value of the hazard quotient relative to the development of resistance was greater than $1.0(\mathrm{HQr}=28.9 \pm 1.9)$, which indicates a possible risk. The presence of carbapenemase-encoding genes in hospital effluent biofilm strains and their ability to transfer are therefore a potential hazard that should not be neglected and points to the need for monitoring antibiotic resistance in hospital wastewater.

Keywords

Biofilm, Carbapenemase, Hospital effluent, Plasmids, Carbapenem 


\section{Introduction}

In the last few decades, antibiotics have been widely used as anti-infectious agents in humans and animals leading to an increase in the percentage of antibiotic-resistant bacteria. Carbapenems are beta-lactam antibiotics with a broad spectrum of activity and are usually considered as the last line of defense against severe infections, mainly those due to multidrug resistant Gram-negative bacteria. In France, carbapenem consumption increased rapidly between 2012 and 2016 from 0.021 to 0.033 dose per 1000 inhabitants per day. This increase was correlated with a rise in the rates of carbapenem-resistant bacteria mostly in a clinical setting (European Surveillance of Antimicrobial Consumption, 2017). Resistance to carbapenems is mainly due to the production of inactivating enzymes, i.e. carbapenemases (Nordmann et al., 2011b, 2011a). A recent survey showed that in Europe, 1.3 patients per 10000 hospital admissions developed infectious diseases caused by carbapenemase-producing Klebsiella pneumoniae or Escherichia coli, with the highest incidence found in southern and southeastern Europe (European Surveillance of Antimicrobial Consumption, 2017). Likewise, the World Health Organization recently published a list of antibiotic-resistant pathogens for which new and effective antibiotics are urgently needed (WHO, 2017) with the first priority being focused on carbapenem-resistant bacterial genus. Carbapenemresistant strains have been detected in human samples but have also been isolated from animal and environmental samples including food, drinking water and wastewater (Jin et al., 2017; Nasri et al., 2017; White et al., 2016; Zurfluh et al., 2017). Such efficient dissemination is probably related to the capacity of the genes encoding the carbapenem-inactivating enzymes to spread within the bacterial world. The carbapenemase-encoding genes most frequently expressed by clinical isolates (KPC, VIM, NDM, GES and OXA-48) are often carried by mobile genetic elements that ensure their maintenance and spread among Gram-negative bacteria (Logan and Weinstein, 2017). Hospital sewage could constitute a privileged place for such dissemination events. First, the bacterial load is heavy, comprising a mixture of antibiotic-resistant clinical pathogens and environmental bacteria aggregated in biofilm structures (Hocquet et al., 2016; Rodriguez-Mozaz et al., 2015), which have a high capacity of colonization and survival in wastewater systems.

Second, antibiotics are present at low concentrations in hospital effluent. After administration to patients, a large part of the native antibiotic molecules and their metabolites are excreted into wastewater, together with the resistant bacteria potentially selected in their digestive tracts 
(Chagas et al., 2011; Chang et al., 2010; Längin et al., 2009; Vaz-Moreira et al., 2016). Antibiotics such as fluoroquinolones, sulfonamides and macrolides are frequently detected in wastewater, especially in hospital effluents and surface water (Gros et al., 2013; Le et al., 2016; Lien et al., 2016; Szekeres et al., 2017). In contrast, and despite their intensive use, beta-lactams, owing to their low chemical stability, are rarely detected in hospital effluents (Deshpande et al., 2004). The selective pressure exerted by these molecules is therefore questionable.

In this study, we assessed the presence of carbapenem (imipenem)-resistant bacteria in biofilms formed in the pipes carrying the hospital effluent, and characterized the antibiotic resistance patterns of the isolates. The presence of antibiotics facilitates the emergence of resistance even at sub-MIC concentrations and so we investigated the amount of imipenem theoretically present in the hospital effluent and determined its effective life in laboratory conditions.

\section{Material and Methods}

\subsection{Hospital effluent sampling}

The samples were collected three times a day for two weeks from the effluent of the Gabriel Montpied hospital, Clermont-Ferrand (139,500 inhabitants) France (latitude 45.7589632; longitude 3.0941279), which is a medium-size hospital with 1,100 beds that operates $24 \mathrm{~h}$ a day with a peak of activity from $7 \mathrm{a} . \mathrm{m}$ to $1 \mathrm{p} . \mathrm{m}$. Water consumption is $13,500-16,000 \mathrm{~m}^{3}$ monthly, between 409 and $478 \mathrm{~L} / \mathrm{bed} /$ day. The hospital effluent is directly discharged into the urban sewage network without any external connection and then into the municipal WWTP, "Les Trois Rivières", which receives and treats about $1,700,000 \mathrm{~m}^{3}$ a month.

The experimental sampling tank $(110 \mathrm{~cm}-50 \mathrm{~cm}-50 \mathrm{~cm})$ was located on a line receiving exclusively wastewater from the hospital upstream of the connection a pipe that collects rainwater before discharge in the public network wastewater. The physical and chemical characteristics of the hospital effluent have been assessed previously (Ory et al., 2016).

\subsection{Environmental risk assessment of imipenem}

Measured environmental concentrations (MEC) of imipenem in the effluent were determined with six polar organic chemical integrative samplers (POCIS) containing $200 \mathrm{mg}$ Oasis HLB® (Exposmeter, Tavelsjo, Sweden). The POCIS were fixed in the effluent tank for 15 days. Quantitative analysis of imipenem was performed by direct injections of filtered $(0.7 \mu \mathrm{m}$ glass 
fiber filter) wastewater on Ultra Performance Liquid Chromatography/Mass Spectrometry system (UPLC/MS/MS, Waters). Due to high instability of carbapenems in presence of organic solvent, no prior sample reconcentration step could be applied. Limit of detection has been evaluated at 2 $\mu \mathrm{g} / \mathrm{L}$ (limit of quantification: $5 \mu \mathrm{g} / \mathrm{L}$ ).

The predicted environmental concentration (PEC) and ecotoxicological risk (hazard quotient, HQ) were estimated as follows. The consumption of imipenem by patients in Gabriel Montpied hospital during the study period was assessed with PHARMA software (Computer Engineering, Paris, France) and the amount potentially released in the hospital effluent calculated according to pharmacokinetic parameters [www.theriaque.org, www.drugs.com]. The PEC was calculated as previously described (Ory et al., 2016). The environmental risk of imipenem was defined according to its HQ, which is the quotient between PEC and the predicted no effect concentration (PNEC). The PNEC used in this study $(78 \mu \mathrm{g} / \mathrm{L})$ was previously established (Bengtsson-Palme and Larsson, 2016). In addition, the environmental risk of resistance selection in microbial communities was calculated by determining the hazard quotient resistance (HQr), i.e. the quotient between PEC and $\mathrm{PNEC}_{\mathrm{MIC}}$, the latter being calculated from the sample size-adjusted lowest MICs from the European Committee on Antimicrobial Susceptibility Testing (EUCAST) database with an assessment factor of 10 (Bengtsson-Palme and Larsson, 2016) .

\subsection{Measurement of the effective life of imipenem}

The stability of imipenem was evaluated by determining its activity on the imipenem-susceptible strain Escherichia coli K12 C600 using the agar (Müller Hinton, MH) diffusion test. A stock solution of imipenem (Sigma-Aldrich, Lyon, France) was made at a concentration of $1 \mathrm{mg} \cdot \mathrm{mL}^{-1}$ and kept at $26^{\circ} \mathrm{C}$ throughout the experiment. For each assay, $10 \mu \mathrm{l}$ of a solution containing $10 \mu \mathrm{g}$ of imipenem were loaded onto sterile $10 \mathrm{~mm}$-diameter paper discs, which were then applied onto a bacterial lawn deposited by swabbing a bacterial suspension $(\mathrm{McF}$ arland $=0.6$ ) onto $\mathrm{MH}$ agar plates. The negative and positive controls consisted of paper discs impregnated with saline and commercialized imipenem disks $(10 \mu \mathrm{g})$ (Bio-Rad, Ivry-sur-Seine, France) stored at $4^{\circ} \mathrm{C}$. The experiment was repeated in triplicate every 6 hours for 54 hours. The diameters of the inhibition zone were measured after $18 \mathrm{~h}$ of incubation at $37^{\circ} \mathrm{C}$.

The stability of imipenem was also measured by determining the bactericidal effect in MH broth medium buffered at $\mathrm{pH}$ 7.2. A total of $100 \mu \mathrm{l}$ of imipenem solution $\left(1 \mathrm{mg} . \mathrm{mL}^{-1}\right)$ freshly prepared 
was added to $10 \mathrm{ml}$ of $E$. coli $\mathrm{C} 600$ suspension (McFarland =4) in $\mathrm{MH}$ broth. After 2 hours of incubation at $37^{\circ} \mathrm{C}$ under agitation, the number of colony forming units (CFU) was determined by plating serial dilutions of the bacterial suspensions onto $\mathrm{MH}$ agar plates further incubated for 18 hours at $37^{\circ} \mathrm{C}$. The experiment was repeated every 6 hours for 54 hours and included controls (without antibiotic).

\subsection{In situ biofilm formation and characterization of imipenem-resistant isolates}

Biofilms were formed on glass slides $(75 \times 26 \mathrm{~mm})$ stuck on a rectangular granite slab placed at the bottom of the hospital effluent wastewater tank. The slides were disposed in the direction of the flow and were constantly submerged without any drying period for 15 days (09/04/2014 to 23/04/2014) to allow the development of substantial biofilm biomass. Each glass slide was collected in Falcon tubes filled with $50 \mathrm{~mL}$ of saline to rinse the biofilm and remove planktonic cells. Glass slides $(n=32)$ were then scratched with a razor blade and sonicated for 5 min in a total volume of $50 \mathrm{~mL}$ saline to disrupt the biofilm (Ory et al., 2016).

Imipenem-resistant bacteria were isolated by spreading serial dilutions (from $10^{-1}$ to $10^{-8}$ ) of the biofilm suspension onto R2A-agar medium without and with imipenem at $8 \mu \mathrm{g} / \mathrm{mL}$ and incubated at $30{ }^{\circ} \mathrm{C}$ for up to $48 \mathrm{~h}$ in aerobic conditions. The resulting colonies were counted, isolated and identified by Gram staining and mass spectrometer analysis (Vitek MS, bioMérieux, La Balme, France) or $16 \mathrm{~S}$ DNA sequencing with primers 27F-1492R (Lane, 1991). The percentage of imipenem-resistant isolates among the cultivable bacteria was determined by comparing the number of $\mathrm{CFU} / \mathrm{mL}$ obtained after growth with and without antibiotic in the medium.

The imipenem MICs among the isolates were determined by the broth dilution method (4 to 256 $\mu \mathrm{g} / \mathrm{mL}$ ) in Mueller-Hinton medium (EUCAST, 2018).

The antibiotic resistance pattern of the isolates was determined by agar diffusion susceptibility testing (EUCAST Guidelines): ampicillin (Amp, $10 \mu \mathrm{g}$ ), ticarcillin (Tic, $75 \mu \mathrm{g}$ ), piperacillin +tazobactam (Ptz, 30/6 $\mu \mathrm{g}$ ), Amoxicillin-clavulanic acid (Amc, 20-10 $\mu \mathrm{g}$ ), cephazolin (Czn, 30 $\mu \mathrm{g}$ ), cefalexin $(\mathrm{Cn}, 30 \mu \mathrm{g})$, cefoxitin (Fox, $30 \mu \mathrm{g}$ ), cefotaxime (Cox, $5 \mu \mathrm{g}$ ), ceftazidime (Czd,10 $\mu \mathrm{g}$ ), cefuroxime (Cxn, $30 \mu \mathrm{g}$ ), cefixime (Fix, $5 \mu \mathrm{g}$ ), cefepime (Fep, $30 \mu \mathrm{g}$ ), mecillinam (Mec, 10 $\mu \mathrm{g}$ ), ertapenem (Etp, $10 \mu \mathrm{g}$ ), aztreonam (Atm, $30 \mu \mathrm{g}$ ), temocillin (Tem, $30 \mu \mathrm{g}$ ), gentamicin (Gmn, $10 \mu \mathrm{g}$ ), netilmicin (Ntm, $10 \mu \mathrm{g}$ ), tobramycin (Tmn, $10 \mu \mathrm{g}$ ), amikacin (Amk, $30 \mu \mathrm{g})$, nalidixic acid 
(Nal, $30 \mu \mathrm{g}$ ), norfloxacin (Nxn, $10 \mu \mathrm{g}$ ), ofloxacin (Ofx, $5 \mu \mathrm{g}$ ), ciprofloxacin (Cip, $5 \mu \mathrm{g}$ ), chloramphenicol (Chl, $30 \mu \mathrm{g}$ ), trimethoprim and sulfamethoxazole (Stx/Tmp, $25 \mu \mathrm{g}$ ), tetracycline (Tet,30 $\mu \mathrm{g}$ ), $200 \mu \mathrm{g}$ ), rifampicin (Rif,30 $\mu \mathrm{g}$ ) and colistin (Col, $10 \mu \mathrm{g}$ ) . (Bio-Rad, Ivry-sur-Seine, France). The breakpoint values were interpreted according to the EUCAST guidelines (2018).

\subsection{Detection and analysis of carbapenemase-encoding genes}

All imipenem-resistant isolates were screened by simplex PCR for the presence of carbapenemase genes with primers specific for bla $a_{\mathrm{VIM}}, b l a_{\mathrm{OXA}-48}$, bla $_{\mathrm{GES}}$, bla $_{\mathrm{KPC}}$ and bla ${ }_{\mathrm{NDM}}$ (Table 1). The PCR products were subjected to gel electrophoresis in $1 \%(\mathrm{w} / \mathrm{v})$ agarose gel and sequenced by external Sanger sequencing services (GATC Biotech, Germany).

\subsection{Transfer capacities of carbapenemase-encoding genes from effluent isolates}

Plasmid DNA from biofilm isolates was extracted with the miniprep plasmid DNA method (Birnboim and Doly, 1979) and analyzed by electrophoresis in a $0.7 \%$ agarose gel. Purified plasmid DNA was subjected to electroporation into E. coli Top10 according to the manufacturer's instructions (Bio-Rad, Ivry-sur-Seine, France). Bacterial suspensions were plated onto LB agar plates containing $2 \mu \mathrm{g} / \mathrm{ml}$ imipenem. Resulting colonies (transformants) were checked by performing PCR with carbapenemase-specific primers and their phenotypical antibiotic resistance pattern determined by agar diffusion testing as described above.

Mating experiments were performed with E.coli C600 as a recipient strain, only resistant to rifampicin. Briefly, the imipenem resistant donor (wild-type effluent isolates or transformants) and recipient strains were grown in $\mathrm{LB}$ medium overnight at $37^{\circ} \mathrm{C}$ and then mixed $(1: 1$ ratio) in $10 \mathrm{ml}$ of $\mathrm{LB}$ fresh medium. After $2 \mathrm{~h}$ of incubation at $37^{\circ} \mathrm{C}$, transconjugants were selected by plating serial dilutions of the suspensions onto LB agar plates supplemented with imipenem and rifampicin $(2 \mu \mathrm{g} / \mathrm{ml}$ and $75 \mu \mathrm{g} / \mathrm{ml}$, respectively). The presence of carbapenemase-encoding genes in selected transconjugants was assessed by specific PCRs and by determination of the phenotypical antibiotic resistance pattern as described above. The conjugative characteristics were determined by calculating the capacity of transfer (ratio transconjugant/donor CFU/ml).

\subsection{Plasmids analysis by S1-nuclease PFGE}


The plasmid content from wild-type effluent strains, transformants, and transconjugants was analyzed by pulse field gel electrophoresis (PFGE) after S1 nuclease digestion (Barton et al., 1995). All PFGE reagents used were from Bio-Rad (CHEF Genomic DNA Plug Kits). Genomic DNA agarose blocks were digested with S1endonuclease (New England Biolab) for 90 min at $37^{\circ} \mathrm{C}$, and then loaded into $1 \%$ electrophoretic agarose gel and run with the CHEF-DR II system (Bio-Rad), with a specific program 1-10s,18h, 6V/cm (voltage, pulse time, and electrophoretic time) at $14^{\circ} \mathrm{C}$. The gels were then stained with Gel Star ${ }^{\circledR}$ (Lonza, Rockland, ME USA) and analyzed by FPQuest@ software (BioRad, Marne la Coquette, France).

\section{Results}

\subsection{Assessment of imipenem in the hospital effluent and determination of its in vitro stability}

The chemical and physical parameters of the hospital effluent were as follows : $\mathrm{pH} 8 \pm 0.2$; temperature $26.2 \pm 0.7{ }^{\circ} \mathrm{C}$; conductivity $873.2 \pm 66.2 \mu \mathrm{Sm} / \mathrm{Cm}$; Total Organic Carbon $216.8 \pm$ 47.5 mg/L; Dissolved Organic Carbon $193.6 \pm 42.4$ mg/L; Total Carbon $229.7 \pm 40.9$ mg/L (Ory et al., 2016). Analysis of POCIS incubated in the hospital effluent for 15 days evidenced no imipenem. The in-vitro stability of imipenem at $26^{\circ} \mathrm{C}$ was determined by its biological activity, which indicated that its half-life was about $26 \mathrm{~h}$. No inhibitory effect was evidenced after $45 \mathrm{~h}$ of storage of the antibiotic stock solution (Figures 1 and 2).

The amount of imipenem potentially released in the hospital wastewater was calculated (Table 2). The imipenem HQ was equal to $0.046+/-0.003$ whereas the calculated HQr value was equal to 28.9, indicating a potential risk of antibiotic resistance selection (Table 3).

\subsection{Characterization of biofilm imipenem-resistant isolates}

Culture of effluent biofilm suspensions on non-selective medium led to the isolation of $2.85 \times 10^{5}$ $\mathrm{CFU} / \mathrm{mL}$. The addition of imipenem to the medium resulted in the selection of about $6.3 \times 10^{4}$ CFU/mL, i.e. $22.1 \%$ of the cultivated bacteria. We selected 38 imipenem resistant isolates on the basis of colony characteristics (size, color, aspect). Their identification indicated that they belonged to 8 different bacterial genera, mostly within Gamma-Proteobacteria (Table 4). Members of the Aeromonadaceae family were the most prevalent (60.5\%), followed by Pseudomonaceae (26.3\%). 
Antibiotic susceptibility testing indicated that half of the isolates had multiresistant phenotypes including five antibiotic classes, betalactams, fluoroquinolones, tetracyclin, aminoglycosides, and trimethoprime-sulfamethoxazole (Table 4). The MIC of imipenem was higher than $32 \mu \mathrm{g} / \mathrm{ml}$ for $89.5 \%$ of the isolates $(\mathrm{n}=34 / 38)$ and higher than $256 \mu \mathrm{g} / \mathrm{ml}$ for $23.7 \%(\mathrm{n}=9 / 38)$. Pseudomonas spp. and Stenotrophomonas spp. isolates had the highest MICs (Table 4).

Detection of the carbapenemase-encoding genes by PCR and sequencing showed that 15 strains harbored at least one of the following carbapenemase-encoding genes, bla $a_{\mathrm{VIM}}$ (11), bla $_{\mathrm{NDM}}$ (1) and bla OXA-48 $_{\text {(2); three strains harbored bla }}$ (2ES encoding genes, one carbapenemase and two extended-spectrum beta-lactamase genes (Table 4).

\subsection{Plasmid analysis of carbapenem-resistant isolates}

Plasmid DNA was extracted from eight wild-type strains belonging to different genera (Aeromonas spp., Stenotrophomonas spp. and Pseudomonas spp.) harboring various carbapenemase-encoding genes (bla $a_{\mathrm{VIM}}$, bla $\mathrm{OXA}_{\mathrm{OA}-48}$, bla $_{\mathrm{NDM}}$ and $\left.b l a_{\mathrm{GES}}\right)$ and with imipenem MICs greater than $32 \mu \mathrm{g} / \mathrm{ml}$. Transformants $E$. coli resistant to imipenem were obtained with each plasmid extract and up to four phenotypic profiles were observed for each set of transformants according to their resistance profiles (Table 4). The presence of bla $a_{\mathrm{VIM}}$ and $b l a_{\mathrm{NDM}}$ was evidenced in two transformants. Using the transformants harboring bla $a_{\mathrm{VIM}}$ as donator strains, mating experiments gave rise to imipenem-resistant transconjugants at a frequency of $2.2510^{-5}$ per input donor. No transconjugant was obtained when transformants harboring bla $a_{\mathrm{NDM}}$ as donator strains were used despite multiple attempts.

Plasmid analysis by S1-nuclease PFGE evidenced at least two plasmids in only four out of the eight selected wild-type strains (Table 4). The wild-type Aeromonas hydrophila/sobria VIM-19 (GEMH7) harbored two plasmids, around $97 \mathrm{~kb}$ and $194 \mathrm{~kb}$. Only the smaller of the two was evidenced in the respective imipenem resistant E. coli transformants in which, however, no carbapenemase-encoding gene was detected by PCR (Table 4). Two plasmids (molecular weight around $97 \mathrm{~kb}$ and $200 \mathrm{~kb}$ ) were also evidenced in both the wild-type Aeromonas hydrophila VIM19 (GEMH9) and its transformants and transconjugants, where bla $a_{\mathrm{VIM}-19}$ was detected by PCR (Table 4). The two other wild-type strains (GEMH52 and GEMH13) gave rise to transformants harboring plasmids but no carbapenemase encoding genes were detected (Table 4). 


\section{Discussion}

The sources of antibiotic resistance in the environment tend to be multifactorial. However, excessive human, veterinary, and agricultural use of antimicrobial products together with the low efficacy of sewage treatment are major causative factors. Antibiotics and their metabolites released into WWTP persist in treated effluents and contaminate surface waters (Korzeniewska et al., 2013; Osińska et al., 2016; White et al., 2016). One of the main environmental problems caused by hospital effluents is due to their discharge in urban sewerage systems without preliminary treatment of the high loads of pharmaceuticals and antibiotic resistant bacteria that they contain. However, the likelihood of active molecules being detected in the effluents depends on the compound's initial concentration, its stability and the sensitivity of testing methods. Betalactams are the most commonly prescribed antibiotics worldwide but they are unstable and few studies have addressed the presence of penicillin and cephalosporin in wastewater (Dinh et al., 2017; Gros et al., 2013; Nielsen et al., 2013; Szekeres et al., 2017). Carbapenems are betalactams mainly used in hospitals as the last line of defense against severe infections. To our knowledge only a few studies, performed in Romania and Belgium, have reported the presence of imipenem in hospital wastewater (Haller et al., 2018; Szekeres et al., 2017). In our study, we focused on imipenem because it is the carbapenem molecule most frequently used in the Clermont-Ferrand teaching hospital, with a PEC of $3.51 \pm 0.24 \mu \mathrm{g} / \mathrm{L}$. The detection limit of our analytical method was $2 \mu \mathrm{g} / \mathrm{L}$ and therefore the passive sampling device used for collecting molecules over time should have allowed quantification of imipenem in the hospital wastewater samples. However, we were unable to detect the molecule in the hospital effluent even after 15 days of collection, owing probably to the high instability of the molecule in wastewater. We did not search for non-active metabolites. In addition, there could be a weak capacity of accumulation of imipenem in POCIS device. New analytical developments, more robust and sensitive need to be investigated and the real capacity of POCIS device to accumulate carbapenems needs to be assessed. Evaluation of the in-vitro biological effectiveness of an imipenem solution stored at $26^{\circ} \mathrm{C}$, the average hospital effluent temperature, showed a rapid and complete loss of activity within a few hours (Figures 1-2). Imipenem is thus probably rapidly 
degraded in non-active metabolites in the effluents because of the high temperature of the wastewater and its alkaline $\mathrm{pH}(\mathrm{pH} 8)$, which enhances beta-lactam degradation (Elragehy et al., 2008; Smith et al., 1990). However, the daily discharge of imipenem in the hospital effluent, despite its instability, could exert a continuous selective pressure.

Because it has rarely been detected in complex environments, imipenem has never been associated with risk. The environmental risk of toxic substances is usually assessed on the basis of the hazard quotient (HQ), which is the ratio between the PEC and the highest concentration of the substance without any harmful effect on the environment (PNEC). In our study, the effluent hospital HQ of imipenem was low (=0.046), suggesting no potential toxicity for the environment. However, the environmental risk assessment of resistance selection in microbial communities (HQr) was greater than 1 (=28.9), indicating the capacity to select resistant species. The PNEC $\mathrm{MIC}_{\mathrm{C}}$ widely used to calculate HQr derives from the study of clinical strains and might not be strictly applicable to environmental species such as Aeromonas spp (Bengtsson-Palme and Larsson, 2016). It is noteworthy that sub-MICs of antibiotics can also exert selective pressure on local microorganisms and thus contribute to the emergence of resistance (Karkman et al., 2017; Murray et al., 2018). Hospital wastewaters contain a variety of antibiotics of variable lifetime (Le et al., 2016), which gives rise to hazardous mixtures in which imipenem could contribute to a synergic toxic effect.

In our study, $22.1 \%$ of the culturable cells from biofilms formed in the hospital effluent were resistant to imipenem. The most frequent species was Aeromonas spp, which is often intrinsically resistant to carbapenem owing to chromosome-encoded beta-lactamase production (Ko et al., 1998; Rasmussen and Bush, 1997; Rossolini and Walsh, Timothy amicosante, 1996; Stunt et al., 1998; Walsh, 2008). Carbapenem resistance-related impermeability mechanisms have also been described in such environmental strains (Yordanov and Strateva, 2009). However, we were able to detect carbapenemase-encoding genes such as bla $a_{\mathrm{OXA} 48}, b l a_{\mathrm{GES}}, b l a_{\mathrm{NDM}}$ and $b l a_{V I M}$ in the effluent biofilm isolates of this study, some of which were plasmid-encoded (bla $a_{\mathrm{VIM}}$ and $b l a_{\mathrm{NDM}}$ 6). The ability of plasmids harboring bla $_{\mathrm{VIM}}$ to widely spread (Queenan and Bush, 2007; Tato et al., 2010) could explain the high frequency of bla $\mathrm{VIM}_{\mathrm{M}}$ among the hospital effluent isolates. The carbapenemase-encoding genes bla $a_{\mathrm{NDM}}, b l a_{\mathrm{VIM}}$ and $b l a_{\mathrm{KPC}}$ have already been detected in Aeromonas spp isolated in aquatic samples (Hughes et al., 2016; Libisch et al., 2008; Subirats et al., 2017; Walsh et al., 2011). 
The high number of imipenem resistant strains detected in the effluent was not related to the rate of resistance observed in the local hospital setting. Indeed, very few clinical strains harboring carbapenemase were isolated in our hospital from 2012 to 2017. They harbored mainly bla $a_{\text {OXA-48 }}$ ( 1 strain in 2012, 1 in 2013, 2 in 2014, 1 in 2015, 3 in 2016, 1 in 2017) and more rarely bla $a_{N D M}(1$ strain in 2014, 1 in 2016 and 1 in 2017) and bla $a_{\mathrm{VIM}}$ (1 strain in 2016 and 1 in 2017) (data not shown).In addition, these strains belong mostly to Escherichia coli and Klebsiella pneumoniae, genera not detected in the hospital biofilm effluent. We cannot exclude the possibility that mobile genetic elements were exchanged between environmental and clinical strains despite our failure to obtain transconjugants in vitro mating assays using wild-type strains harboring carbapenemase- encoding conjugative plasmids as donors. It is noteworthy, however, that transconjugants were obtained when $E$. coli transformants harboring imipenem bla $\mathrm{VIM}_{\mathrm{V}}$-encoding plasmid were used as donors. Similar observations have been made by other workers (Kieffer et al., 2016; Ramoul et al., 2016), suggesting that conjugation events are promoted under specific conditions encountered in situ and that only the most environmentally adapted species such as Aeromonas would survive in the long term within the highly competitive community of biofilms. The bacterial biofilm content of hospital effluent would thus not mirror the ecology of circulating clinical strains in a low prevalence context of carbapenemase-encoding clinical strains such as that encountered in our hospital. However, persistent aquatic communities in the environment are potential crossroads for antibiotic multi-resistance strains. Indeed, analysis of the antibiotic resistance phenotype of the imipenem-resistant transformants obtained in this study showed that additional resistances had been co-transferred, indicating a co-localization of antibiotic resistance genes on plasmids, as reported elsewhere (Samuelsen et al., 2009; Xie et al., 2017).

In conclusion, while specific treatment of hospital wastewater is often recommended to limit the dissemination of anti-microbial resistance mechanisms, our study shows that these treatments should also target the biofilm cells aggregated on the pipe surfaces.

\section{Acknowledgments}

The authors thank Christophe Portelli and Paul Alain Nana for providing field and laboratory assistance. We are also grateful to Chantal Rich, Alexis Pontvianne and Laurent Guillouard for their technical assistance. We thank Vincent Pinon for providing the data of medicine consumption. 


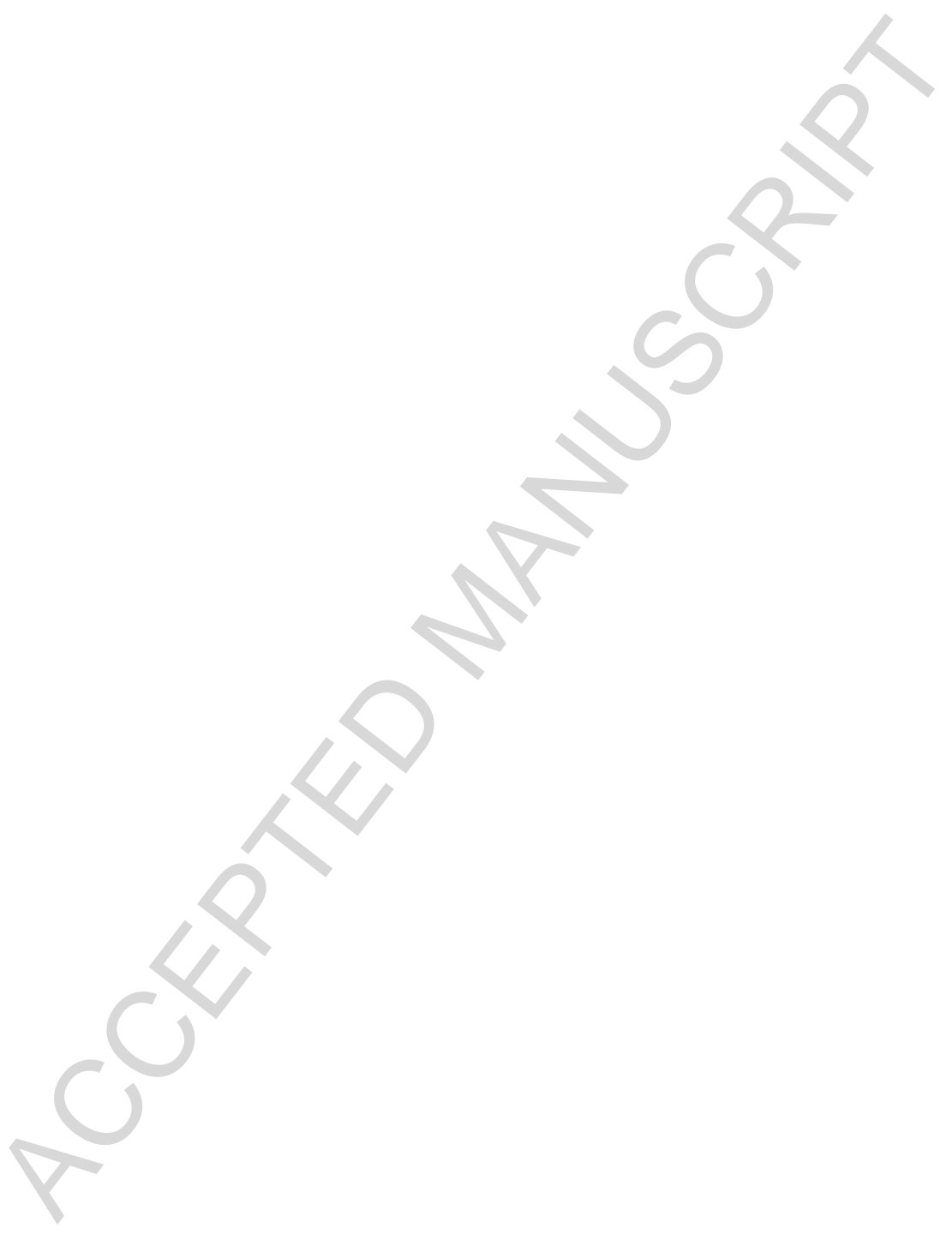




\section{References}

Barton, B.M., Harding, G.P., Zuccarelli, A.J., 1995. A General Method for Detecting and Sizing Large Plasmids. Anal. Biochem. 226, 235-240. https://doi.org/10.1006/abio.1995.1220

Bengtsson-Palme, J., Larsson, D.G.J., 2016. Concentrations of antibiotics predicted to select for resistant bacteria: Proposed limits for environmental regulation. Environ. Int. 86, 140-149. https://doi.org/10.1016/j.envint.2015.10.015

Birnboim, H., Doly, J., 1979. Nucleic Acids Research. Nucleic Acids Res. 7, ii-ii. https://doi.org/10.1093/nar/gkn907

Chagas, T.P.G., Seki, L.M., da Silva, D.M., Asensi, M.D., 2011. Occurrence of KPC-2-producing Klebsiella pneumoniae strains in hospital wastewater. J. Hosp. Infect. 77, 281. https://doi.org/10.1016/j.jhin.2010.10.008

Chang, X., Meyer, M.T., Liu, X., Zhao, Q., Chen, H., Chen, J., Qiu, Z., Yang, L., Cao, J., Shu, W., 2010. Determination of antibiotics in sewage from hospitals, nursery and slaughter house, wastewater treatment plant and source water in Chongqing region of Three Gorge Reservoir in China. Environ. Pollut. 158, 1444-1450. https://doi.org/10.1016/j.envpol.2009.12.034

Deshpande, A.D., Baheti, K.G., Chatterjee, N.R., 2004. Degradation of $\beta$-lactam antibiotics. Curr. Sci. https://doi.org/10.2307/24109765

Dinh, Q.T., Moreau-Guigon, E., Labadie, P., Alliot, F., Teil, M.-J., Blanchard, M., Chevreuil, M., 2017. Occurrence of antibiotics in rural catchments. Chemosphere 168, 483-490. https://doi.org/10.1016/j.chemosphere.2016.10.106

Elragehy, N.A., Abdel-Moety, E.M., Hassan, N.Y., Rezk, M.R., 2008. Stability-indicating determination of meropenem in presence of its degradation product. Talanta 77, 28-36. https://doi.org/10.1016/j.talanta.2008.06.045

European Committee on Antimicrobial Susceptibility Testing Guidelines (EUCAST), 2018. European Surveillance of Antimicrobial Consumption, 2017. European Surveillance of Antimicrobial Consumption Network (ESAC-Net) [WWW Document]. URL https://ecdc.europa.eu/en/about-us/partnerships-and-networks/disease-and-laboratorynetworks/esac-net (accessed 8.5.17).

Gros, M., Rodríguez-Mozaz, S., Barceló, D., 2013. Rapid analysis of multiclass antibiotic residues and some of their metabolites in hospital, urban wastewater and river water by ultra-high-performance liquid chromatography coupled to quadrupole-linear ion trap tandem mass spectrometry. J. Chromatogr. A 1292, 173-188. https://doi.org/10.1016/j.chroma.2012.12.072

Haller, L., Chen, H., Ng, C., Le, T.H., Koh, T.H., Barkham, T., Sobsey, M., Gin, K.Y.H., 2018. Occurrence and characteristics of extended-spectrum $\beta$-lactamase- and carbapenemaseproducing bacteria from hospital effluents in Singapore. Sci. Total Environ. 615, 11191125. https://doi.org/10.1016/j.scitotenv.2017.09.217

Hocquet, D., Muller, A., Bertrand, X., 2016. What happens in hospitals does not stay in hospitals: antibiotic-resistant bacteria in hospital wastewater systems. J. Hosp. Infect. 93, 395-402. https://doi.org/10.1016/j.jhin.2016.01.010

Hughes, H.Y., Conlan, S.P., Lau, A.F., Dekker, J.P., Michelin, A. V., Youn, J.H., Henderson, D.K., Frank, K.M., Segre, J.A., Palmorea, T.N., 2016. Detection and whole-genome sequencing of carbapenemase- producing Aeromonas hydrophila isolates from routine perirectal surveillance culture. J. Clin. Microbiol. 54, 1167-1170.

https://doi.org/10.1128/JCM.03229-15 
Jin, L., Wang, R., Wang, X., Wang, Q., Zhang, Y., Yin, Y., Wang, H., 2017. Emergence of mcr-1 and carbapenemase genes in hospital sewage water in Beijing, China. J. Antimicrob. Chemother. 84-87. https://doi.org/10.1093/jac/dkx355

Karkman, A., Do, T.T., Walsh, F., Virta, M.P.J., 2017. Antibiotic-Resistance Genes in Waste Water. Trends Microbiol. 26, 220-228. https://doi.org/10.1016/j.tim.2017.09.005

Kieffer, N., Poirel, L., Bessa, L.J., Barbosa-Vasconcelos, A., da Costa, P.M., Nordmann, P., 2016. VIM-1, VIM-34, and IMP-8 Carbapenemase-Producing Escherichia coli Strains Recovered from a Portuguese River. Antimicrob. Agents Chemother. 60, 2585-2586. https://doi.org/10.1128/AAC.02632-15

Ko, W.C., Wu, H.M., Chang, T.C., Yan, J.J., Wu, J.J., 1998. Inducible beta-lactam resistance in Aeromonas hydrophila: therapeutic challenge for antimicrobial therapy. J. Clin. Microbiol. 36, 3188-92. https://doi.org/0095-1137/98/\$04.0010

Korzeniewska, E., Korzeniewska, A., Harnisz, M., 2013. Antibiotic resistant Escherichia coli in hospital and municipal sewage and their emission to the environment. Ecotoxicol. Environ. Saf. 91, 96-102. https://doi.org/10.1016/j.ecoenv.2013.01.014

Lane, D.J., 1991. 16S/23S rRNA sequencing. In: editors, in: Stackebrandt, E, Goodfellow, M. (Ed.), Nucleic Acid Techniques in Bacterial Systematics. John Wiley and Sons, New York, NY, p. 115-175.

Längin, A., Alexy, R., König, A., Kümmerer, K., 2009. Deactivation and transformation products in biodegradability testing of $\beta$-lactams amoxicillin and piperacillin. Chemosphere 75, 347354. https://doi.org/10.1016/j.chemosphere.2008.12.032

Le, T.-H., Ng, C., Chen, H., Yi, X.Z., Koh, T.H., Barkham, T.M.S., Zhou, Z., Gin, K.Y.-H., 2016. Occurrences and Characterization of Antibiotic Resistant Bacteria and Genetic Determinants of Hospital Wastewaters in a Tropical Country. Antimicrob. Agents Chemother. 60, AAC.01556-16. https://doi.org/10.1128/AAC.01556-16

Libisch, B., Giske, C.G., Kovács, B., Tóth, T.G., Füzi, M., 2008. Identification of the first VIM metallo-beta-lactamase-producing multiresistant Aeromonas hydrophila strain. J. Clin. Microbiol. 46, 1878-80. https://doi.org/10.1128/JCM.00047-08

Lien, L.T.Q., Hoa, N.Q., Chuc, N.T.K., Thoa, N.T.M., Phuc, H.D., Diwan, V., Dat, N.T., Tamhankar, A.J., Lundborg, C.S., 2016. Antibiotics in Wastewater of a Rural and an Urban Hospital before and after Wastewater Treatment, and the Relationship with Antibiotic UseA One Year Study from Vietnam. Int. J. Environ. Res. Public Health 13. https://doi.org/10.3390/ijerph13060588

Logan, L.K., Weinstein, R.A., 2017. The Epidemiology of Carbapenem-Resistant Enterobacteriaceae: The Impact and Evolution of a Global Menace. J. Infect. Dis. 215, S28-S36. https://doi.org/10.1093/infdis/jiw282

Murray, A.K., Zhang, L., Yin, X., Zhang, T., Buckling, A., Snape, J., Gaze, W.H., 2018. Novel Insights into Selection for Antibiotic Resistance in Complex Microbial Communities. MBio 9, e00969-18. https://doi.org/10.1128/mBio.00969-18

Nasri, E., Subirats, J., Sànchez-Melsió, A., Mansour, H. Ben, Borrego, C.M., Balcázar, J.L., 2017. Abundance of carbapenemase genes (blaKPC, blaNDM and blaOXA-48) in wastewater effluents from Tunisian hospitals. Environ. Pollut. 229, 371-374. https://doi.org/10.1016/j.envpol.2017.05.095

Nielsen, U., Hastrup, C., Klausen, M.M., Pedersen, B.M., Kristensen, G.H., Jansen, J.L.C., Bak, S.N., Tuerk, J., 2013. Removal of APIs and bacteria from hospital wastewater by MBR plus O3, $\mathrm{O} 3+\mathrm{H} 2 \mathrm{O} 2$, PAC or ClO2. Water Sci. Technol. 67. https://doi.org/10.2166/wst.2012.645 
Nordmann, P., Naas, T., Poirel, L., 2011a. Global Spread of Carbapenemase-producing. Emerg. Infect. Dis. 17, 1791-1798. https://doi.org/10.3201/eid1710.110655

Nordmann, P., Picazo, J.J., Mutters, R., Korten, V., Quintana, A., Laeuffer, J.M., Seak, J.C.H., Flamm, R.K., Morrissey, I., Azadian, B., El-Bouri, K., Jones, G., Masterton, B., Morgan, M., Oppenheim, B., Waghorn, D., Smyth, E., Abele-Horn, M., Jacobs, E., Mai, U., Mutters, R., Pfister, W., Schoerner, C., Seifert, H., Bebear, C., Bingen, E., Bonnet, R., Jehl, F., Levy, P.-Y., Nordmann, P., Delvallez, M.R., Paniara, O., Papaparaskevas, J., Piotr, H., Kolar, M., Zemlickova, H., Hanzen, J., Kotulova, D., Campa, M., Fadda, G., Fortina, G., Gesu, G., Manso, E., Milano, F., Nicoletti, G., Pucillo, L., Rigoli, R., Rossolini, G., Sambri, V., Sarti, M., Akalin, H., Sinirtas, M., Akova, M., Hascelik, G., Arman, D., Dizbay, M., Aygen, B., Sumerkan, B., Dokuzoguz, B., Esener, H., Eraksoy, H., Basaran, S., Koksal, I., Bayramoglu, G., Korten, V., Soyletir, G., Ulusoy, S., Tunger, A., Yalcin, A.N., Ogunc, D., Bou, G., Bouza, E., Canton, R., Coll, P., Garcia-Rodriguez, J.A., Gimeno, C., Gobernado, M., Bertomeu, F.G., Gomez-Garces, J.L., Marco, F., Martinez-Martinez, L., Pascual, A., Perez, J.L., Picazo, J., Prats, G., Linares, M.S., Ghaly, F., Cristino, M., Diogo, J., Ramos, H., Balode, A., Jurna-Ellam, M., Koslov, R., 2011b. Comparative activity of carbapenem testing: the COMPACT study. J. Antimicrob. Chemother. 66, 1070-1078. https://doi.org/10.1093/jac/dkr056

Ory, J., Bricheux, G., Togola, A., Bonnet, J.L., Donnadieu-Bernard, F., Nakusi, L., Forestier, C., Traore, O., 2016. Ciprofloxacin residue and antibiotic-resistant biofilm bacteria in hospital effluent. Environ. Pollut. 214, 635-645. https://doi.org/10.1016/j.envpol.2016.04.033

Osińska, A., Harnisz, M., Korzeniewska, E., 2016. Prevalence of plasmid-mediated multidrug resistance determinants in fluoroquinolone-resistant bacteria isolated from sewage and surface water. Environ. Sci. Pollut. Res. 23, 10818-10831. https://doi.org/10.1007/s11356016-6221-4

Queenan, A.M., Bush, K., 2007. Carbapenemases: the versatile beta-lactamases. Clin. Microbiol. Rev. 20, 440-58, table of contents. https://doi.org/10.1128/CMR.00001-07

Ramoul, A., Loucif, L., Bakour, S., Amiri, S., Dekhil, M., Rolain, J.-M., 2016. Co-occurrence of bla NDM-1 with bla OXA-23 or bla OXA-58 in clinical multidrug-resistant Acinetobacter baumannii isolates in Algeria. J. Glob. Antimicrob. Resist. 6, 136-141. https://doi.org/10.1016/j.jgar.2016.05.003

Rasmussen, B.A., Bush, K., 1997. Carbapenem-hydrolyzing beta-lactamases. Antimicrob. Agents Chemother. 41, 223-32. https://doi.org/0066-4804/97/\$04.00 0

Rodriguez-Mozaz, S., Chamorro, S., Marti, E., Huerta, B., Gros, M., Sànchez-Melsió, A., Borrego, C.M., Barceló, D., Balcázar, J.L., 2015. Occurrence of antibiotics and antibiotic resistance genes in hospital and urban wastewaters and their impact on the receiving river. Water Res. 69, 234-242. https://doi.org/10.1016/j.watres.2014.11.021

Rossolini, G.M., Walsh, Timothy amicosante, G., 1996. The Aeromonas Metallo- $\beta$-Lactamases: Genetics, Enzymology, and Contribution to Drug Resistance. Microb. Drug Resist. 2, 245 252. https://doi.org/10.1089/mdr.1996.2.245

Samuelsen, O., Naseer, U., Tofteland, S., Skutlaberg, D.H., Onken, A., Hjetland, R., Sundsfjord, A., Giske, C.G., 2009. Emergence of clonally related Klebsiella pneumoniae isolates of sequence type 258 producing plasmid-mediated KPC carbapenemase in Norway and Sweden. J. Antimicrob. Chemother. 63, 654-658. https://doi.org/10.1093/jac/dkp018

Smith, G.B., Dezeny, G.C., Douglas, A.W., Currie, S.A., Jackson, M., Stapley, E.O., Miller, T.W., Miller, A.K., Hendlin, D., Mochales, S., Hernandez, S., Woodruff, H.B., Birnbaum, J., 1990. Stability and Kinetics of Degradation of Imipenem in Aqueous Solution. J. Pharm. 
Sci. 79, 732-740. https://doi.org/10.1002/jps.2600790816

Stunt, R., Thomson, C.J., Payne, D.J., Amyes, S.G., 1998. A study of the mechanisms involved in imipenem resistance in Pseudomonas aeruginosa isolates from Japan. J. Antimicrob. Chemother. 42, 272-273. https://doi.org/10.1093/jac/42.2.272

Subirats, J., Royo, E., Balcázar, J.L., Borrego, C.M., 2017. Real-time PCR assays for the detection and quantification of carbapenemase genes (bla KPC, bla NDM, and bla OXA-48) in environmental samples. Environ. Sci. Pollut. Res. https://doi.org/10.1007/s11356-0178426-6

Szekeres, E., Baricz, A., Chiriac, C.M., Farkas, A., Opris, O., Soran, M.-L., Andrei, A.-S., Rudi, K., Balcázar, J.L., Dragos, N., Coman, C., 2017. Abundance of antibiotics, antibiotic resistance genes and bacterial community composition in wastewater effluents from different Romanian hospitals. Environ. Pollut. 225, 304-315. https://doi.org/10.1016/j.envpol.2017.01.054

Tato, M., Coque, T.M., Baquero, F., Canton, R., 2010. Dispersal of Carbapenemase blaVIM-1 Gene Associated with Different Tn402 Variants, Mercury Transposons, and Conjugative Plasmids in Enterobacteriaceae and Pseudomonas aeruginosa. Antimicrob. Agents Chemother. 54, 320-327. https://doi.org/10.1128/AAC.00783-09

Vaz-Moreira, I., Varela, A.R., Pereira, T. V., Fochat, R.C., Manaia, C.M., 2016. Multidrug Resistance in Quinolone-Resistant Gram-Negative Bacteria Isolated from Hospital Effluent and the Municipal Wastewater Treatment Plant. Microb. Drug Resist. 22, 155-163. https://doi.org/10.1089/mdr.2015.0118

Walsh, T.R., 2008. Clinically significant carbapenemases: an update. Curr. Opin. Infect. Dis. 21, 367-371. https://doi.org/10.1097/QCO.0b013e328303670b

Walsh, T.R., Weeks, J., Livermore, D.M., Toleman, M.A., 2011. Dissemination of NDM-1 positive bacteria in the New Delhi environment and its implications for human health: an environmental point prevalence study. Lancet Infect. Dis. 11, 355-362. https://doi.org/10.1016/S1473-3099(11)70059-7

White, L., Hopkins, K.L., Meunier, D., Perry, C.L., Pike, R., Wilkinson, P., Pickup, R.W., Cheesbrough, J., Woodford, N., 2016. Carbapenemase-producing Enterobacteriaceae in hospital wastewater: a reservoir that may be unrelated to clinical isolates. J. Hosp. Infect. 93, 145-151. https://doi.org/10.1016/j.jhin.2016.03.007

WHO, 2017. Antimicrobial Resistance. World Heal. Organ.

Xie, L., Dou, Y., Zhou, K., Chen, Y., Han, L., Guo, X., Sun, J., 2017. Coexistence of blaOXA-48 and Truncated blaNDM-1 on Different Plasmids in a Klebsiella pneumoniae Isolate in China. Front. Microbiol. 8. https://doi.org/10.3389/fmicb.2017.00133

Yordanov, D., Strateva, T., 2009. Pseudomonas aeruginosa - a phenomenon of bacterial resistance. J. Med. Microbiol. 58, 1133-1148. https://doi.org/10.1099/jmm.0.009142-0

Zurfluh, K., Bagutti, C., Brodmann, P., Alt, M., Schulze, J., Fanning, S., Stephan, R., NüeschInderbinen, M., 2017. Wastewater is a reservoir for clinically relevant carbapenemase and 16s rRNA methylase producing Enterobacteriaceae. Int. J. Antimicrob. Agents. https://doi.org/10.1016/j.ijantimicag.2017.04.017 
Table 1. Oligonucleotides used in this study

\begin{tabular}{|c|c|c|c|c|c|c|}
\hline & & $\begin{array}{c}\text { Primers' } \\
\text { names }\end{array}$ & Sequence $\left(5^{\prime}-3^{\prime}\right)$ & Ref * & $\begin{array}{c}\text { Hybridation } \\
\left({ }^{\circ} \mathrm{C}\right)\end{array}$ & $\begin{array}{c}\text { Expected } \\
\text { product size } \\
\text { (bp) }\end{array}$ \\
\hline \multirow{12}{*}{ 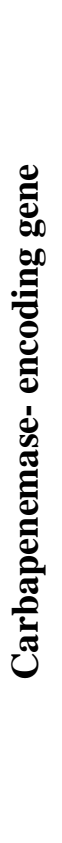 } & \multirow{2}{*}{$b l a \mathrm{KPC}$} & $\mathrm{KPC}-\mathrm{F}$ & ATG TCA CTG TAT CGC CGT CT & \multirow{2}{*}{ This work } & \multirow[t]{2}{*}{54} & \multirow[t]{2}{*}{881} \\
\hline & & KPC-R & TTA CTG CCC GTT GAC GCC CA & & & \\
\hline & \multirow{2}{*}{$b l a \mathrm{NDM}$} & preNDM A & CAC CTC ATG TTT GAA TTC GCC & \multirow{2}{*}{ This work } & & \multirow[t]{2}{*}{832} \\
\hline & & preNDM B & CTC TGT CAC ATC GAA ATC GC & & & \\
\hline & \multirow{2}{*}{$b l a{ }_{\mathrm{GES}}$} & GES-F & GGA ATT CCA TAT GCG CTT CAT TCA CGC ACT A & \multirow{2}{*}{ This work } & \multirow[t]{2}{*}{60} & \multirow[t]{2}{*}{891} \\
\hline & & GES-R & ATA GTT TAG CGG CCG CCC TAT TTG TCC GTG CTC AGG & & & \\
\hline & \multirow{2}{*}{$b l a$ VIM-1 } & VIM-1A NdeI & GGA ATT CCAB TAT GTT AAA AGT TAT TAG TAG T & \multirow{2}{*}{ Robin et al., } & \multirow[t]{2}{*}{60} & \multirow[t]{2}{*}{829} \\
\hline & & VIM-1B NotI & ATA GTT TAG CGG CCG CCC TAC TCG GCG ACT GAG CGA TT & & & \\
\hline & \multirow{2}{*}{$b l a$ VIM-2 } & VIM-F & GGA ATT CCA TAT GTT CAA ACT TTT GAG TAA G & \multirow{2}{*}{ This work } & \multirow[t]{2}{*}{60} & \multirow[t]{2}{*}{828} \\
\hline & & VIM-R & ATA GTT TAG CGG CCG CCC TAC TCA ACG ACT G & & & \\
\hline & \multirow{2}{*}{$b l a_{\mathrm{OXA}-48}$} & OXA-F bis & GGG GAC GTT ATG CGT GTA TT & \multirow{2}{*}{ This work } & \multirow[t]{2}{*}{60} & \multirow[t]{2}{*}{780} \\
\hline & & OXA-R bis & GAG CAC TTC TTT TGT GAT GGC & & & \\
\hline
\end{tabular}

*For the design of new carbapenemase detection primers used in this work, sequences were downloaded from the GenBank database and aligned using the ClustalX software (version 2.0). The different primers were designed using the FastPCR software.

Robin, F., Aggoune-Khinache, N., Delmas, J., Naim, M., Bonnet, R., 2010. Novel VIM metallo- $\beta$-lactamase variant from clinical isolates of Enterobacteriaceae from Algeria. Antimicrob. Agents Chemother. 54, 466-470. https://doi.org/10.1128/AAC.00017-09.

PCR cycles were as follows : $95^{\circ} \mathrm{C} 15 \mathrm{~s}$, then 30 cycles : $95^{\circ} \mathrm{C} 30 \mathrm{~s}$, hybridation temperature $1 \mathrm{~min} 30,72^{\circ} \mathrm{C} 30 \mathrm{~s}$; final elongation $72{ }^{\circ} \mathrm{C} 10 \mathrm{~min}$ 
Table 2. Consumption of imipenem at the Gabriel Montpied hospital over the 2 week-analysis and pharmacokinetic parameters used to estimate the amount of imipenem potentially released in the hospital wastewater.

\begin{tabular}{|c|c|c|c|c|c|c|c|c|}
\hline Molecule & $\begin{array}{c}\text { Route of } \\
\text { administration }\end{array}$ & Form & $\begin{array}{l}\text { Quantity } \\
\text { (mg) }\end{array}$ & Consumption & $\begin{array}{c}q=\text { Quantity } \\
\text { consumed } \\
(\mu g)\end{array}$ & $\begin{array}{c}\% \text { dose } \\
\text { urinary } \\
\text { excretion } \\
\text { (min-max) }\end{array}$ & $\begin{array}{l}\% \text { dose } \\
\text { fecal } \\
\text { excretion }\end{array}$ & $\begin{array}{c}Q=\text { Quantity of } \\
\text { unchanged drug } \\
\text { eliminated by organism } \\
(\mu \mathrm{g})\end{array}$ \\
\hline $\begin{array}{l}\text { Imipenem } \\
\text { and } \\
\text { cilastatin }\end{array}$ & Intravenous & $\begin{array}{l}\text { Infusion } \\
\text { solution }\end{array}$ & 500 & 152 & $7.610^{+07}$ & & $<1 \%$ & $5.70^{+07}+/-3.8^{+06}$ \\
\hline
\end{tabular}


Table 3. Predicted Environmental Concentration (PEC), Predicted No-Effect Concentrations (PNEC), Predicted No-Effect Concentrations according to Minimum Inhibitory Concentration (MIC) and determination of the Hazard quotient (HQ) and Hazard Quotient resistance (HQr) for Imipenem

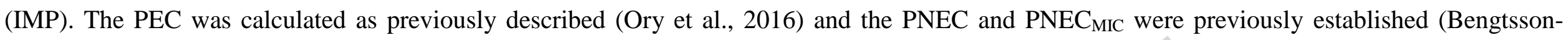
Palme and Larsson, 2016).

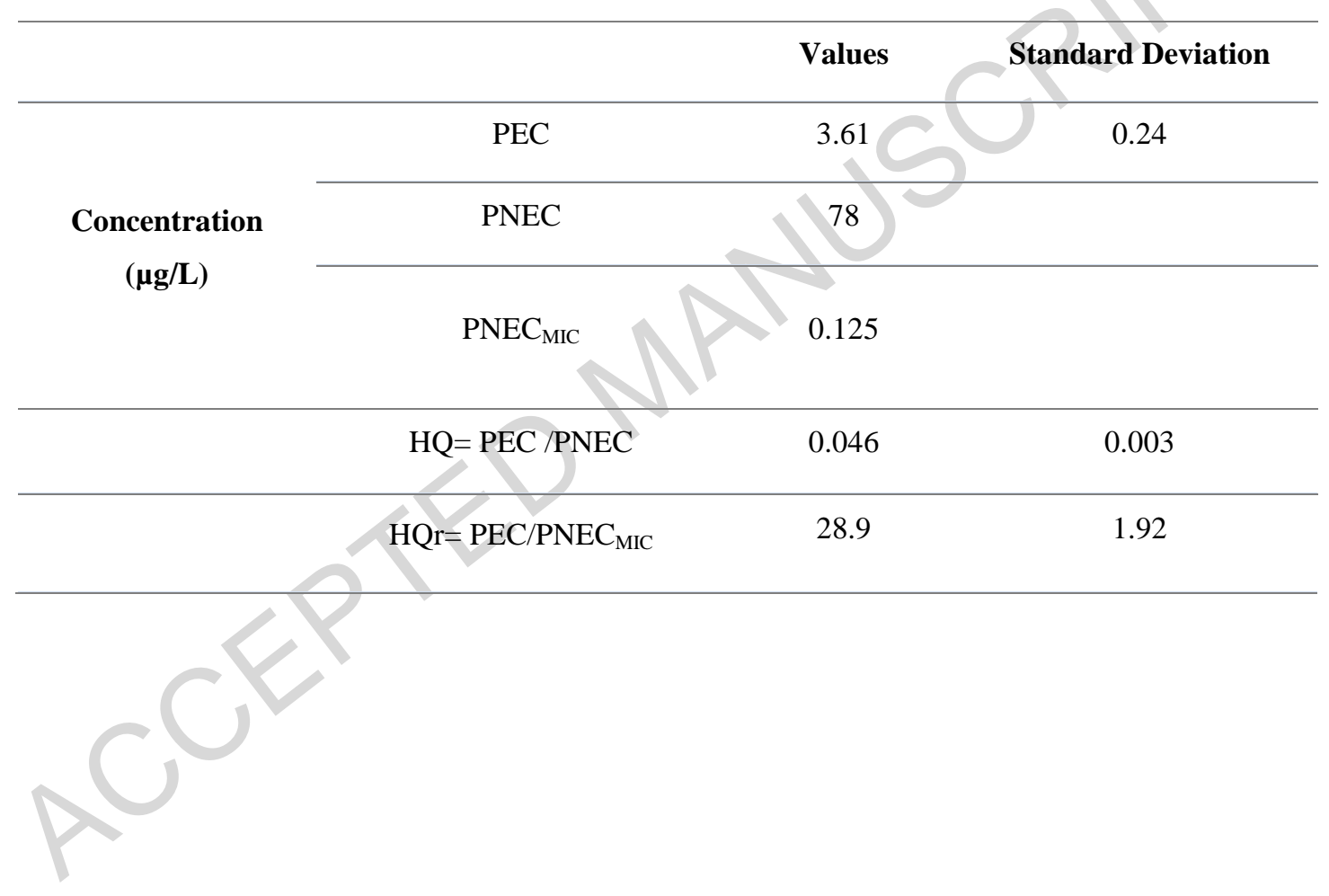


Table 4. Antibiotic resistance pattern of wild-type (WT) strains isolated from effluent biofilm and their E. coli transformants (T) on agar plate containing imipenem. The minimum inhibitory concentrations (MICs) of imipenem are indicated for each isolate. The antibiotic resistance pattern was determined by agar diffusion susceptibility testing after $18 \mathrm{~h}$ of incubation at $37^{\circ} \mathrm{C}$. The carbapenemase/extended-spectrum beta-lactamase (ESBL)-encoding genes detected by PCR and sequence analysis are indicated for each isolate: bla $\mathrm{VIM}_{\mathrm{M}}$, bla $\mathrm{O}_{\mathrm{OXA}-48}$, bla $\mathrm{GES}_{\mathrm{GES}}$ anda $\mathrm{NDM}_{\text {. }}$

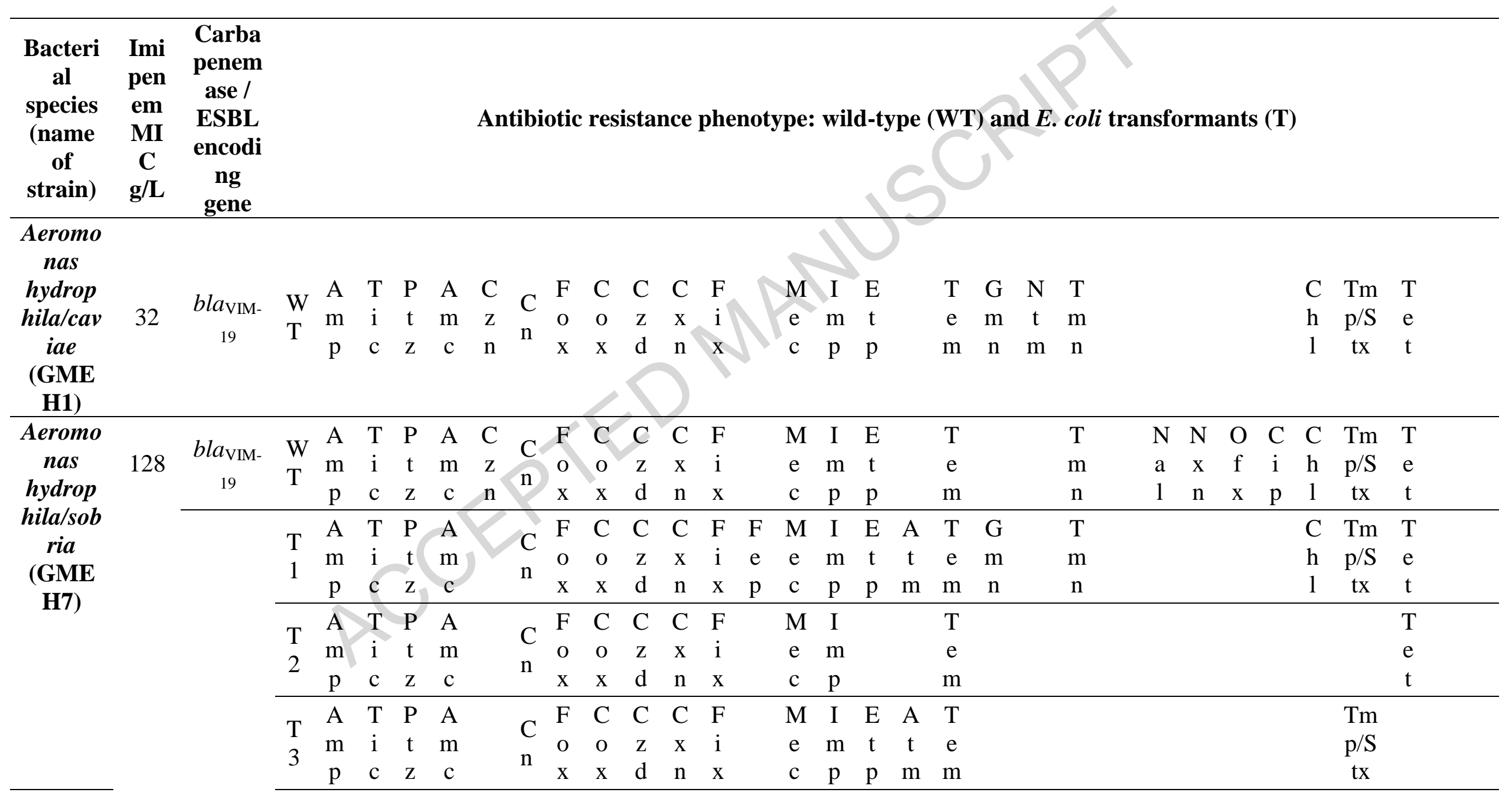




\begin{tabular}{|c|c|c|c|c|c|c|c|c|c|c|c|c|c|c|c|c|c|c|c|c|c|c|c|c|c|c|c|c|c|c|c|c|c|}
\hline & & & $\begin{array}{l}\mathrm{T} \\
4\end{array}$ & $\begin{array}{l}\mathrm{A} \\
\mathrm{m} \\
\mathrm{p}\end{array}$ & $\begin{array}{l}\mathrm{T} \\
\mathrm{i} \\
\mathrm{c}\end{array}$ & $\begin{array}{l}P \\
t \\
z\end{array}$ & $\begin{array}{l}\mathrm{A} \\
\mathrm{m} \\
\mathrm{c}\end{array}$ & & $\begin{array}{l}\mathrm{C} \\
\mathrm{n}\end{array}$ & $\begin{array}{l}\mathrm{F} \\
\mathrm{o} \\
\mathrm{X}\end{array}$ & $\begin{array}{l}\mathrm{C} \\
\mathrm{O} \\
\mathrm{X}\end{array}$ & $\begin{array}{l}\text { C } \\
\mathrm{z} \\
\mathrm{d}\end{array}$ & $\begin{array}{l}\mathrm{C} \\
\mathrm{x} \\
\mathrm{n}\end{array}$ & $\begin{array}{l}\mathrm{F} \\
\mathrm{i} \\
\mathrm{x}\end{array}$ & & $\begin{array}{l}\mathrm{M} \\
\mathrm{e} \\
\mathrm{c}\end{array}$ & $\begin{array}{l}\mathrm{I} \\
\mathrm{m} \\
\mathrm{p}\end{array}$ & & & $\begin{array}{l}\mathrm{T} \\
\mathrm{e} \\
\mathrm{m}\end{array}$ & $\begin{array}{c}\mathrm{G} \\
\mathrm{m} \\
\mathrm{n}\end{array}$ & $\begin{array}{c}\mathrm{N} \\
\mathrm{t} \\
\mathrm{m}\end{array}$ & $\begin{array}{l}\mathrm{T} \\
\mathrm{m} \\
\mathrm{n}\end{array}$ & & & & & & $\begin{array}{l}\mathrm{C} \\
\mathrm{h} \\
1\end{array}$ & $\begin{array}{c}\mathrm{Tm} \\
\mathrm{p} / \mathrm{S} \\
\mathrm{tx}\end{array}$ & $\begin{array}{l}\mathrm{T} \\
\mathrm{e} \\
\mathrm{t}\end{array}$ & & \\
\hline $\begin{array}{c}\text { Aeromo } \\
\text { nas } \\
\text { hydrop } \\
\text { hila/cav } \\
\text { iae } \\
\text { (GME } \\
\text { H8) }\end{array}$ & 32 & & $\begin{array}{l}\mathrm{W} \\
\mathrm{T}\end{array}$ & $\begin{array}{c}\mathrm{A} \\
\mathrm{m} \\
\mathrm{p}\end{array}$ & & $\begin{array}{l}P \\
t \\
z\end{array}$ & & & $\begin{array}{l}\mathrm{C} \\
\mathrm{n}\end{array}$ & $\begin{array}{l}\mathrm{F} \\
\mathrm{o} \\
\mathrm{x}\end{array}$ & $\begin{array}{l}\mathrm{C} \\
\mathrm{O} \\
\mathrm{X}\end{array}$ & $\begin{array}{l}\text { C } \\
\mathrm{z} \\
\mathrm{d}\end{array}$ & $\begin{array}{l}\mathrm{C} \\
\mathrm{x} \\
\mathrm{n}\end{array}$ & $\begin{array}{l}\mathrm{F} \\
\mathrm{i} \\
\mathrm{x}\end{array}$ & $\begin{array}{l}\mathrm{F} \\
\mathrm{e} \\
\mathrm{p}\end{array}$ & $\begin{array}{l}\mathrm{M} \\
\mathrm{e} \\
\mathrm{c}\end{array}$ & $\begin{array}{l}\mathrm{I} \\
\mathrm{m} \\
\mathrm{p}\end{array}$ & $\begin{array}{l}\mathrm{E} \\
\mathrm{t} \\
\mathrm{p}\end{array}$ & $\begin{array}{c}\mathrm{A} \\
\mathrm{t} \\
\mathrm{m}\end{array}$ & $\begin{array}{l}\mathrm{T} \\
\mathrm{e} \\
\mathrm{m}\end{array}$ & & & & & & & & & & & & & \\
\hline $\begin{array}{c}\text { Aeromo } \\
\text { nas } \\
\text { hydrop }\end{array}$ & 32 & $\begin{array}{c}\text { bla }_{\mathrm{VIM}-} \\
19\end{array}$ & $\begin{array}{l}\mathrm{W} \\
\mathrm{T}\end{array}$ & $\begin{array}{c}\mathrm{A} \\
\mathrm{m} \\
\mathrm{p}\end{array}$ & $\begin{array}{l}\mathrm{T} \\
\mathrm{i} \\
\mathrm{c}\end{array}$ & $\begin{array}{l}P \\
t \\
z\end{array}$ & $\begin{array}{l}\mathrm{A} \\
\mathrm{m} \\
\mathrm{c}\end{array}$ & $\begin{array}{l}\mathrm{C} \\
\mathrm{z} \\
\mathrm{n}\end{array}$ & $\begin{array}{l}\mathrm{C} \\
\mathrm{n}\end{array}$ & $\begin{array}{l}\mathrm{F} \\
\mathrm{O} \\
\mathrm{X}\end{array}$ & $\begin{array}{l}\mathrm{C} \\
\mathrm{O} \\
\mathrm{X}\end{array}$ & $\begin{array}{l}\mathrm{C} \\
\mathrm{z} \\
\mathrm{d}\end{array}$ & $\begin{array}{l}\mathrm{C} \\
\mathrm{x} \\
\mathrm{n}\end{array}$ & $\begin{array}{l}\mathrm{F} \\
\mathrm{i} \\
\mathrm{x}\end{array}$ & & $\begin{array}{l}\mathrm{M} \\
\mathrm{e} \\
\mathrm{c}\end{array}$ & $\begin{array}{l}\mathrm{I} \\
\mathrm{m} \\
\mathrm{p}\end{array}$ & $\begin{array}{l}E \\
t \\
p\end{array}$ & $\begin{array}{l}\mathrm{A} \\
\mathrm{t} \\
\mathrm{m}\end{array}$ & $\begin{array}{l}\mathrm{T} \\
\mathrm{e} \\
\mathrm{m}\end{array}$ & $V$ & & $\begin{array}{l}\mathrm{T} \\
\mathrm{m} \\
\mathrm{n}\end{array}$ & & $\begin{array}{l}\mathrm{N} \\
\mathrm{a} \\
\mathrm{l}\end{array}$ & & & $\begin{array}{l}\mathrm{C} \\
\mathrm{i} \\
\mathrm{p}\end{array}$ & $\begin{array}{l}\mathrm{C} \\
\mathrm{h} \\
\mathrm{l}\end{array}$ & $\begin{array}{c}\mathrm{Tm} \\
\mathrm{p} / \mathrm{S} \\
\mathrm{tx}\end{array}$ & $\begin{array}{l}\mathrm{T} \\
\mathrm{e} \\
\mathrm{t}\end{array}$ & $\begin{array}{l}\mathrm{C} \\
\mathrm{o} \\
1\end{array}$ & \\
\hline $\begin{array}{c}\text { hila } \\
\text { (GME } \\
\text { H9) }\end{array}$ & & & $\begin{array}{l}\mathrm{T} \\
1\end{array}$ & $\begin{array}{l}\mathrm{A} \\
\mathrm{m} \\
\mathrm{p}\end{array}$ & $\begin{array}{l}\mathrm{T} \\
\mathrm{i} \\
\mathrm{c}\end{array}$ & & $\begin{array}{l}\mathrm{A} \\
\mathrm{m} \\
\mathrm{c}\end{array}$ & & & & & & & & & $\begin{array}{l}\mathrm{M} \\
\mathrm{e} \\
\mathrm{c}\end{array}$ & $\begin{array}{l}\mathrm{I} \\
\mathrm{m} \\
\mathrm{p}\end{array}$ & $\begin{array}{l}E \\
t \\
p\end{array}$ & $\begin{array}{c}\mathrm{A} \\
\mathrm{t} \\
\mathrm{m}\end{array}$ & $\begin{array}{l}\mathrm{T} \\
\mathrm{e} \\
\mathrm{m}\end{array}$ & $\begin{array}{c}\mathrm{G} \\
\mathrm{m} \\
\mathrm{n}\end{array}$ & & $\begin{array}{l}\mathrm{T} \\
\mathrm{m} \\
\mathrm{n}\end{array}$ & & & & & & $\begin{array}{l}\mathrm{C} \\
\mathrm{h} \\
1\end{array}$ & $\begin{array}{c}\mathrm{Tm} \\
\mathrm{p} / \mathrm{S} \\
\mathrm{tx}\end{array}$ & $\begin{array}{l}\mathrm{T} \\
\mathrm{e} \\
\mathrm{t}\end{array}$ & & \\
\hline & & $\begin{array}{c}b l a_{\mathrm{VIM}-} \\
19\end{array}$ & $\begin{array}{l}\mathrm{T} \\
2\end{array}$ & $\begin{array}{l}\mathrm{A} \\
\mathrm{m} \\
\mathrm{p}\end{array}$ & $\begin{array}{l}\mathrm{T} \\
\mathrm{i} \\
\mathrm{c}\end{array}$ & $\begin{array}{l}P \\
t \\
z\end{array}$ & $\begin{array}{l}\mathrm{A} \\
\mathrm{m} \\
\mathrm{c}\end{array}$ & & $\mathrm{C}$ & $\begin{array}{l}\mathrm{F} \\
\mathrm{o} \\
\mathrm{X}\end{array}$ & $\begin{array}{l}\mathrm{C} \\
\mathrm{o} \\
\mathrm{X}\end{array}$ & $\begin{array}{l}\mathrm{C} \\
\mathrm{z} \\
\mathrm{d}\end{array}$ & $\begin{array}{l}\mathrm{C} \\
\mathrm{x} \\
\mathrm{n}\end{array}$ & $\begin{array}{l}\mathrm{F} \\
\mathrm{i} \\
\mathrm{x}\end{array}$ & $V$ & $\begin{array}{l}\mathrm{M} \\
\mathrm{e} \\
\mathrm{c}\end{array}$ & $\begin{array}{l}\mathrm{I} \\
\mathrm{m} \\
\mathrm{p}\end{array}$ & & & $\begin{array}{l}\mathrm{T} \\
\mathrm{e} \\
\mathrm{m}\end{array}$ & & & & & & & & & & & & & \\
\hline \multirow{4}{*}{$\begin{array}{c}\text { Aeromo } \\
\text { nas } \\
\text { hydrop } \\
\text { hila/sob } \\
\text { ria } \\
\text { (GME } \\
\text { H10) }\end{array}$} & \multirow[t]{4}{*}{64} & $\begin{array}{c}b l a_{N D M} \\
-6\end{array}$ & $\begin{array}{l}\mathrm{W} \\
\mathrm{T}\end{array}$ & $\begin{array}{c}\mathrm{A} \\
\mathrm{m} \\
\mathrm{p}\end{array}$ & $\begin{array}{l}\mathrm{T} \\
\mathrm{i} \\
\mathrm{c}\end{array}$ & $\begin{array}{l}P \\
t \\
z\end{array}$ & $\begin{array}{l}\mathrm{A} \\
\mathrm{m} \\
\mathrm{c}\end{array}$ & & $\begin{array}{l}\mathrm{C} \\
\mathrm{n}\end{array}$ & $\begin{array}{l}\mathrm{F} \\
\mathrm{o} \\
\mathrm{X}\end{array}$ & $\begin{array}{l}\mathrm{C} \\
\mathrm{o} \\
\mathrm{X}\end{array}$ & $\begin{array}{l}\mathrm{C} \\
\mathrm{z} \\
\mathrm{d}\end{array}$ & $\begin{array}{l}\mathrm{C} \\
\mathrm{x} \\
\mathrm{n}\end{array}$ & $\begin{array}{l}\mathrm{F} \\
\mathrm{i} \\
\mathrm{x}\end{array}$ & $\begin{array}{l}\mathrm{F} \\
\mathrm{e} \\
\mathrm{p}\end{array}$ & $\begin{array}{l}\mathrm{M} \\
\mathrm{e} \\
\mathrm{c}\end{array}$ & $\begin{array}{l}\mathrm{I} \\
\mathrm{m} \\
\mathrm{p}\end{array}$ & $\begin{array}{l}\mathrm{E} \\
\mathrm{t} \\
\mathrm{p}\end{array}$ & $\begin{array}{c}\mathrm{A} \\
\mathrm{t} \\
\mathrm{m}\end{array}$ & $\begin{array}{l}\mathrm{T} \\
\mathrm{e} \\
\mathrm{m}\end{array}$ & $\begin{array}{c}\mathrm{G} \\
\mathrm{m} \\
\mathrm{n}\end{array}$ & $\begin{array}{c}\mathrm{N} \\
\mathrm{t} \\
\mathrm{m}\end{array}$ & $\begin{array}{l}\mathrm{T} \\
\mathrm{m} \\
\mathrm{n}\end{array}$ & $\begin{array}{l}\mathrm{A} \\
\mathrm{m} \\
\mathrm{k}\end{array}$ & $\begin{array}{l}\mathrm{N} \\
\mathrm{a} \\
\mathrm{l}\end{array}$ & $\begin{array}{l}\mathrm{N} \\
\mathrm{X} \\
\mathrm{n}\end{array}$ & $\begin{array}{l}\mathrm{O} \\
\mathrm{f} \\
\mathrm{x}\end{array}$ & $\begin{array}{l}\mathrm{C} \\
\mathrm{i} \\
\mathrm{p}\end{array}$ & & $\begin{array}{c}\mathrm{Tm} \\
\mathrm{p} / \mathrm{S} \\
\mathrm{tx}\end{array}$ & $\begin{array}{l}\mathrm{T} \\
\mathrm{e} \\
\mathrm{t}\end{array}$ & $\begin{array}{l}\mathrm{C} \\
\mathrm{o} \\
1\end{array}$ & $\begin{array}{l}\text { R } \\
\text { i } \\
\text { f }\end{array}$ \\
\hline & & & $\begin{array}{l}\mathrm{T} \\
1\end{array}$ & $\begin{array}{l}\mathrm{A} \\
\mathrm{m} \\
\mathrm{p}\end{array}$ & $\begin{array}{l}\mathrm{T} \\
\mathrm{i} \\
\mathrm{c}\end{array}$ & & $\frac{\mathrm{m}}{\mathrm{c}}$ & & & & & & & & & $\begin{array}{l}\mathrm{M} \\
\mathrm{e} \\
\mathrm{c}\end{array}$ & $\begin{array}{c}\mathrm{I} \\
\mathrm{m} \\
\mathrm{p}\end{array}$ & $\begin{array}{c}E \\
t \\
p\end{array}$ & $\begin{array}{c}\mathrm{A} \\
\mathrm{t} \\
\mathrm{m}\end{array}$ & $\begin{array}{l}\mathrm{T} \\
\mathrm{e} \\
\mathrm{m}\end{array}$ & & & & & & & & & & & & & \\
\hline & & & $\begin{array}{l}\mathrm{T} \\
2\end{array}$ & $\begin{array}{l}\mathrm{A} \\
\mathrm{m} \\
\mathrm{p}\end{array}$ & $\begin{array}{l}\mathrm{T} \\
\mathrm{i} \\
\mathrm{c}\end{array}$ & $\begin{array}{l}\mathrm{P} \\
\mathrm{t} \\
\mathrm{z}\end{array}$ & $\begin{array}{c}\mathrm{A} \\
\mathrm{m} \\
\mathrm{c}\end{array}$ & & $\begin{array}{l}\mathrm{C} \\
\mathrm{n}\end{array}$ & $\begin{array}{l}F \\
\mathrm{O} \\
\mathrm{x}\end{array}$ & $\begin{array}{l}\mathrm{C} \\
\mathrm{O} \\
\mathrm{x}\end{array}$ & $\begin{array}{l}\mathrm{C} \\
\mathrm{z} \\
\mathrm{d}\end{array}$ & $\begin{array}{l}\mathrm{C} \\
\mathrm{x} \\
\mathrm{n}\end{array}$ & $\begin{array}{l}\mathrm{F} \\
\mathrm{i} \\
\mathrm{x}\end{array}$ & $\begin{array}{l}\mathrm{F} \\
\mathrm{e} \\
\mathrm{p}\end{array}$ & $\begin{array}{l}\mathrm{M} \\
\mathrm{e} \\
\mathrm{c}\end{array}$ & $\begin{array}{l}\mathrm{I} \\
\mathrm{m} \\
\mathrm{p}\end{array}$ & & $\begin{array}{c}\mathrm{A} \\
\mathrm{t} \\
\mathrm{m}\end{array}$ & $\begin{array}{l}\mathrm{T} \\
\mathrm{e} \\
\mathrm{m}\end{array}$ & & & & & & & & & & & $\begin{array}{l}\mathrm{T} \\
\mathrm{e} \\
\mathrm{t}\end{array}$ & & \\
\hline & & $\begin{array}{c}b l a_{N D M} \\
-6\end{array}$ & $\begin{array}{l}\mathrm{T} \\
3\end{array}$ & $\begin{array}{l}\mathrm{A} \\
\mathrm{m} \\
\mathrm{p}\end{array}$ & $\begin{array}{l}\mathrm{T} \\
\mathrm{i} \\
\mathrm{c}\end{array}$ & $\begin{array}{l}P \\
t \\
z\end{array}$ & $\begin{array}{c}\mathrm{A} \\
\mathrm{m} \\
\mathrm{c}\end{array}$ & & $\begin{array}{l}\mathrm{C} \\
\mathrm{n}\end{array}$ & $\begin{array}{l}F \\
O \\
X\end{array}$ & $\begin{array}{l}\mathrm{C} \\
\mathrm{o} \\
\mathrm{x}\end{array}$ & $\begin{array}{l}\mathrm{C} \\
\mathrm{z} \\
\mathrm{d}\end{array}$ & $\begin{array}{l}\mathrm{C} \\
\mathrm{x} \\
\mathrm{n}\end{array}$ & $\begin{array}{l}\mathrm{F} \\
\mathrm{i} \\
\mathrm{x}\end{array}$ & & & & & & $\begin{array}{l}\mathrm{T} \\
\mathrm{e} \\
\mathrm{m}\end{array}$ & $\begin{array}{c}\mathrm{G} \\
\mathrm{m} \\
\mathrm{n}\end{array}$ & $\begin{array}{c}\mathrm{N} \\
\mathrm{t} \\
\mathrm{m}\end{array}$ & $\begin{array}{c}\mathrm{T} \\
\mathrm{m} \\
\mathrm{n}\end{array}$ & $\begin{array}{c}\mathrm{A} \\
\mathrm{m} \\
\mathrm{k}\end{array}$ & & & & & & & & & \\
\hline
\end{tabular}




\begin{tabular}{|c|c|c|c|c|c|c|c|c|c|c|c|c|c|c|c|c|c|c|c|c|c|c|c|c|c|c|c|c|c|c|c|}
\hline & & & $\begin{array}{l}\mathrm{T} \\
4\end{array}$ & $\begin{array}{l}\mathrm{A} \\
\mathrm{m} \\
\mathrm{p}\end{array}$ & $\begin{array}{l}\mathrm{T} \\
\mathrm{i} \\
\mathrm{c}\end{array}$ & $\begin{array}{l}P \\
t \\
z\end{array}$ & $\begin{array}{c}\mathrm{A} \\
\mathrm{m} \\
\mathrm{c}\end{array}$ & & $\begin{array}{l}\mathrm{C} \\
\mathrm{n}\end{array}$ & $\begin{array}{l}F \\
0 \\
x\end{array}$ & $\begin{array}{l}\mathrm{C} \\
\mathrm{o} \\
\mathrm{X}\end{array}$ & $\begin{array}{l}\mathrm{C} \\
\mathrm{z} \\
\mathrm{d}\end{array}$ & $\begin{array}{l}\mathrm{C} \\
\mathrm{x} \\
\mathrm{n}\end{array}$ & $\begin{array}{l}\mathrm{F} \\
\mathrm{i} \\
\mathrm{x}\end{array}$ & & $\begin{array}{l}\mathrm{M} \\
\mathrm{e} \\
\mathrm{c}\end{array}$ & $\begin{array}{l}\mathrm{I} \\
\mathrm{m} \\
\mathrm{p}\end{array}$ & & $\begin{array}{l}\mathrm{A} \\
\mathrm{t} \\
\mathrm{m}\end{array}$ & $\begin{array}{l}\mathrm{T} \\
\mathrm{e} \\
\mathrm{m}\end{array}$ & & & & & & & & & & & \\
\hline $\begin{array}{c}\text { Aeromo } \\
\text { nas } \\
\text { spp. } \\
\text { (GME } \\
\text { H11) }\end{array}$ & 128 & & $\begin{array}{l}\mathrm{W} \\
\mathrm{T}\end{array}$ & $\begin{array}{l}\mathrm{A} \\
\mathrm{m} \\
\mathrm{p}\end{array}$ & $\begin{array}{l}\mathrm{T} \\
\mathrm{i} \\
\mathrm{c}\end{array}$ & $\begin{array}{l}P \\
t \\
z\end{array}$ & $\begin{array}{c}\mathrm{A} \\
\mathrm{m} \\
\mathrm{c}\end{array}$ & $\begin{array}{l}\mathrm{C} \\
\mathrm{Z} \\
\mathrm{n}\end{array}$ & $\begin{array}{l}\mathrm{C} \\
\mathrm{n}\end{array}$ & $\begin{array}{l}F \\
0 \\
x\end{array}$ & $\begin{array}{l}\mathrm{C} \\
\mathrm{O} \\
\mathrm{X}\end{array}$ & $\begin{array}{l}\mathrm{C} \\
\mathrm{z} \\
\mathrm{d}\end{array}$ & $\begin{array}{l}\mathrm{C} \\
\mathrm{x} \\
\mathrm{n}\end{array}$ & $\begin{array}{l}\mathrm{F} \\
\mathrm{i} \\
\mathrm{x}\end{array}$ & $\begin{array}{l}\mathrm{F} \\
\mathrm{e} \\
\mathrm{p}\end{array}$ & $\begin{array}{l}\mathrm{M} \\
\mathrm{e} \\
\mathrm{c}\end{array}$ & $\begin{array}{l}\mathrm{I} \\
\mathrm{m} \\
\mathrm{p}\end{array}$ & $\begin{array}{l}E \\
t \\
p\end{array}$ & $\begin{array}{l}\mathrm{A} \\
\mathrm{t} \\
\mathrm{m}\end{array}$ & $\begin{array}{l}\mathrm{T} \\
\mathrm{e} \\
\mathrm{m}\end{array}$ & $\begin{array}{c}\mathrm{G} \\
\mathrm{m} \\
\mathrm{n}\end{array}$ & $\begin{array}{c}\mathrm{N} \\
\mathrm{t} \\
\mathrm{m}\end{array}$ & & & $\begin{array}{l}\mathrm{N} \\
\mathrm{a} \\
\mathrm{l}\end{array}$ & $\begin{array}{l}\mathrm{N} \\
\mathrm{X} \\
\mathrm{n}\end{array}$ & $\begin{array}{l}\mathrm{O} \\
\mathrm{f} \\
\mathrm{x}\end{array}$ & $\begin{array}{l}\mathrm{C} \\
\mathrm{i} \\
\mathrm{p}\end{array}$ & $\begin{array}{l}\mathrm{C} \\
\mathrm{h} \\
1\end{array}$ & $\begin{array}{c}\mathrm{Tm} \\
\mathrm{p} / \mathrm{S} \\
\mathrm{tx}\end{array}$ & $\begin{array}{l}\mathrm{T} \\
\mathrm{e} \\
\mathrm{t}\end{array}$ \\
\hline $\begin{array}{c}\text { Aeromo } \\
\text { nas } \\
\text { sobria } \\
\text { (GME } \\
\text { H15) }\end{array}$ & 64 & & $\begin{array}{l}\mathrm{W} \\
\mathrm{T}\end{array}$ & $\begin{array}{l}\mathrm{A} \\
\mathrm{m} \\
\mathrm{p}\end{array}$ & $\begin{array}{l}\mathrm{T} \\
\mathrm{i} \\
\mathrm{c}\end{array}$ & $\begin{array}{l}P \\
t \\
z\end{array}$ & $\begin{array}{c}\mathrm{A} \\
\mathrm{m} \\
\mathrm{c}\end{array}$ & $\begin{array}{l}\mathrm{C} \\
\mathrm{z} \\
\mathrm{n}\end{array}$ & $\begin{array}{l}\mathrm{C} \\
\mathrm{n}\end{array}$ & $\begin{array}{l}\mathrm{F} \\
\mathrm{o} \\
\mathrm{X}\end{array}$ & $\begin{array}{l}\mathrm{C} \\
\mathrm{o} \\
\mathrm{X}\end{array}$ & $\begin{array}{l}C \\
z \\
d\end{array}$ & $\begin{array}{l}\mathrm{C} \\
\mathrm{x} \\
\mathrm{n}\end{array}$ & $\begin{array}{l}\mathrm{F} \\
\mathrm{i} \\
\mathrm{x}\end{array}$ & $\begin{array}{l}F \\
\mathrm{e} \\
\mathrm{p}\end{array}$ & $\begin{array}{l}\mathrm{M} \\
\mathrm{e} \\
\mathrm{c}\end{array}$ & $\begin{array}{l}\mathrm{I} \\
\mathrm{m} \\
\mathrm{p}\end{array}$ & $\begin{array}{c}E \\
t \\
p\end{array}$ & $\begin{array}{l}\mathrm{A} \\
\mathrm{t} \\
\mathrm{m}\end{array}$ & $\begin{array}{l}\mathrm{T} \\
\mathrm{e} \\
\mathrm{m}\end{array}$ & & $\begin{array}{c}\mathrm{N} \\
\mathrm{t} \\
\mathrm{m}\end{array}$ & & & $\begin{array}{l}\mathrm{N} \\
\mathrm{a} \\
\mathrm{l}\end{array}$ & $\begin{array}{l}\mathrm{N} \\
\mathrm{X} \\
\mathrm{n}\end{array}$ & $\begin{array}{l}\mathrm{O} \\
\mathrm{f} \\
\mathrm{x}\end{array}$ & $\begin{array}{l}\mathrm{C} \\
\mathrm{i} \\
\mathrm{p}\end{array}$ & & $\begin{array}{c}\mathrm{Tm} \\
\mathrm{p} / \mathrm{S} \\
\mathrm{tx}\end{array}$ & \\
\hline $\begin{array}{c}\text { Aeromo } \\
\text { nas } \\
\text { veronii } \\
\text { (GME } \\
\text { H17) }\end{array}$ & 64 & & $\begin{array}{l}\mathrm{W} \\
\mathrm{T}\end{array}$ & $\begin{array}{l}\mathrm{A} \\
\mathrm{m} \\
\mathrm{p}\end{array}$ & $\begin{array}{l}\mathrm{T} \\
\mathrm{i} \\
\mathrm{c}\end{array}$ & $\begin{array}{l}P \\
t \\
z\end{array}$ & $\begin{array}{c}\mathrm{A} \\
\mathrm{m} \\
\mathrm{c}\end{array}$ & $\begin{array}{l}\mathrm{C} \\
\mathrm{z} \\
\mathrm{n}\end{array}$ & $\begin{array}{l}\mathrm{C} \\
\mathrm{n}\end{array}$ & $\begin{array}{l}\mathrm{F} \\
\mathrm{o} \\
\mathrm{X}\end{array}$ & $\begin{array}{l}\mathrm{C} \\
\mathrm{O} \\
\mathrm{X}\end{array}$ & $\begin{array}{l}C \\
z \\
d\end{array}$ & $\begin{array}{l}C \\
x\end{array}$ & $\begin{array}{l}F \\
\mathrm{i} \\
\mathrm{X}\end{array}$ & & $\begin{array}{l}\mathrm{M} \\
\mathrm{e} \\
\mathrm{c}\end{array}$ & $\begin{array}{l}\mathrm{I} \\
\mathrm{m} \\
\mathrm{p}\end{array}$ & $\begin{array}{l}E \\
t \\
p\end{array}$ & $\begin{array}{c}\mathrm{A} \\
\mathrm{t} \\
\mathrm{m}\end{array}$ & $\begin{array}{l}\mathrm{T} \\
\mathrm{e} \\
\mathrm{m}\end{array}$ & $\begin{array}{c}\mathrm{G} \\
\mathrm{m} \\
\mathrm{n}\end{array}$ & $\begin{array}{c}\mathrm{N} \\
\mathrm{t} \\
\mathrm{m}\end{array}$ & $\begin{array}{l}\mathrm{T} \\
\mathrm{m} \\
\mathrm{n}\end{array}$ & & $\begin{array}{l}\mathrm{N} \\
\mathrm{a} \\
\mathrm{l}\end{array}$ & $\begin{array}{l}\mathrm{N} \\
\mathrm{X} \\
\mathrm{n}\end{array}$ & $\begin{array}{l}\mathrm{O} \\
\mathrm{f} \\
\mathrm{x}\end{array}$ & $\begin{array}{l}\mathrm{C} \\
\mathrm{i} \\
\mathrm{p}\end{array}$ & & $\begin{array}{c}\mathrm{Tm} \\
\mathrm{p} / \mathrm{S} \\
\mathrm{tx}\end{array}$ & \\
\hline $\begin{array}{c}\text { Aeromo } \\
\text { nas } \\
\text { hydrop } \\
\text { hila/sob } \\
\text { ria } \\
\text { (GME } \\
\text { H20) }\end{array}$ & 4 & & $\begin{array}{l}\mathrm{W} \\
\mathrm{T}\end{array}$ & $\begin{array}{l}\mathrm{A} \\
\mathrm{m} \\
\mathrm{p}\end{array}$ & $\begin{array}{l}\mathrm{T} \\
\mathrm{i} \\
\mathrm{c}\end{array}$ & $\begin{array}{l}P \\
t \\
z\end{array}$ & & & 1 & $\begin{array}{l}0 \\
x\end{array}$ & & & & $\begin{array}{l}\mathrm{F} \\
\mathrm{i} \\
\mathrm{x}\end{array}$ & $\begin{array}{l}\mathrm{F} \\
\mathrm{e} \\
\mathrm{p}\end{array}$ & $\begin{array}{l}\mathrm{M} \\
\mathrm{e} \\
\mathrm{c}\end{array}$ & $\begin{array}{l}\mathrm{I} \\
\mathrm{m} \\
\mathrm{p}\end{array}$ & $\begin{array}{c}E \\
t \\
p\end{array}$ & & $\begin{array}{l}\mathrm{T} \\
\mathrm{e} \\
\mathrm{m}\end{array}$ & $\begin{array}{c}\mathrm{G} \\
\mathrm{m} \\
\mathrm{n}\end{array}$ & $\begin{array}{c}\mathrm{N} \\
\mathrm{t} \\
\mathrm{m}\end{array}$ & & & $\begin{array}{l}\mathrm{N} \\
\mathrm{a} \\
1\end{array}$ & $\begin{array}{l}\mathrm{N} \\
\mathrm{X} \\
\mathrm{n}\end{array}$ & $\begin{array}{l}\mathrm{O} \\
\mathrm{f} \\
\mathrm{x}\end{array}$ & $\begin{array}{l}\mathrm{C} \\
\mathrm{i} \\
\mathrm{p}\end{array}$ & & & \\
\hline $\begin{array}{c}\text { Aeromo } \\
\text { nas } \\
\text { hydrop } \\
\text { hila } \\
\text { (GME } \\
\text { H24) }\end{array}$ & 32 & & $\begin{array}{l}\mathrm{W} \\
\mathrm{T}\end{array}$ & $\begin{array}{l}\mathrm{A} \\
\mathrm{m} \\
\mathrm{p}\end{array}$ & $\begin{array}{l}\mathrm{T} \\
\mathrm{i} \\
\mathrm{c}\end{array}$ & $\begin{array}{l}P \\
t \\
z\end{array}$ & $\begin{array}{c}\mathrm{A} \\
\mathrm{m} \\
\mathrm{c}\end{array}$ & $\begin{array}{l}\mathrm{C} \\
\mathrm{z} \\
\mathrm{n}\end{array}$ & $\begin{array}{l}\mathrm{C} \\
\mathrm{n}\end{array}$ & $\begin{array}{l}F \\
\mathrm{O} \\
\mathrm{X}\end{array}$ & $\begin{array}{l}\mathrm{C} \\
\mathrm{O} \\
\mathrm{x}\end{array}$ & $\begin{array}{l}\mathrm{C} \\
\mathrm{z} \\
\mathrm{d}\end{array}$ & $\begin{array}{l}\mathrm{C} \\
\mathrm{x} \\
\mathrm{n}\end{array}$ & $\begin{array}{l}\mathrm{F} \\
\mathrm{i} \\
\mathrm{x}\end{array}$ & $\begin{array}{l}\mathrm{F} \\
\mathrm{e} \\
\mathrm{p}\end{array}$ & $\begin{array}{l}\mathrm{M} \\
\mathrm{e} \\
\mathrm{c}\end{array}$ & $\begin{array}{l}\mathrm{I} \\
\mathrm{m} \\
\mathrm{p}\end{array}$ & $\begin{array}{l}E \\
t \\
p\end{array}$ & $\begin{array}{l}\mathrm{A} \\
\mathrm{t} \\
\mathrm{m}\end{array}$ & $\begin{array}{l}\mathrm{T} \\
\mathrm{e} \\
\mathrm{m}\end{array}$ & & $\begin{array}{c}\mathrm{N} \\
\mathrm{t} \\
\mathrm{m}\end{array}$ & $\begin{array}{l}\mathrm{T} \\
\mathrm{m} \\
\mathrm{n}\end{array}$ & & $\begin{array}{l}\mathrm{N} \\
\mathrm{a} \\
1\end{array}$ & & & $\begin{array}{l}\mathrm{C} \\
\mathrm{i} \\
\mathrm{p}\end{array}$ & $\begin{array}{l}\mathrm{C} \\
\mathrm{h} \\
1\end{array}$ & $\begin{array}{c}\mathrm{Tm} \\
\mathrm{p} / \mathrm{S} \\
\mathrm{tx}\end{array}$ & \\
\hline $\begin{array}{c}\text { Aeromo } \\
\text { nas } \\
\text { hydrop } \\
\text { hila/sob }\end{array}$ & 256 & $\begin{array}{c}b_{7} l a_{G E S-} \\
\quad\end{array}$ & $\begin{array}{l}\mathrm{W} \\
\mathrm{T}\end{array}$ & $\begin{array}{l}\mathrm{A} \\
\mathrm{m} \\
\mathrm{p}\end{array}$ & $\begin{array}{l}\mathrm{T} \\
\mathrm{i} \\
\mathrm{c}\end{array}$ & $\begin{array}{l}\mathrm{P} \\
\mathrm{t} \\
\mathrm{z}\end{array}$ & $\begin{array}{c}\mathrm{A} \\
\mathrm{m} \\
\mathrm{c}\end{array}$ & $\begin{array}{l}\mathrm{C} \\
\mathrm{z} \\
\mathrm{n}\end{array}$ & $\begin{array}{l}\mathrm{C} \\
\mathrm{n}\end{array}$ & $\begin{array}{l}\mathrm{F} \\
\mathrm{o} \\
\mathrm{X}\end{array}$ & $\begin{array}{l}\mathrm{C} \\
\mathrm{o} \\
\mathrm{X}\end{array}$ & $\begin{array}{l}\mathrm{C} \\
\mathrm{z} \\
\mathrm{d}\end{array}$ & $\begin{array}{l}\mathrm{C} \\
\mathrm{x} \\
\mathrm{n}\end{array}$ & $\begin{array}{l}\mathrm{F} \\
\mathrm{i} \\
\mathrm{x}\end{array}$ & & $\begin{array}{l}\mathrm{M} \\
\mathrm{e} \\
\mathrm{c}\end{array}$ & $\begin{array}{l}\mathrm{I} \\
\mathrm{m} \\
\mathrm{p}\end{array}$ & $\begin{array}{l}E \\
t \\
p\end{array}$ & & $\begin{array}{l}\mathrm{T} \\
\mathrm{e} \\
\mathrm{m}\end{array}$ & $\begin{array}{c}\mathrm{G} \\
\mathrm{m} \\
\mathrm{n}\end{array}$ & $\begin{array}{c}\mathrm{N} \\
\mathrm{t} \\
\mathrm{m}\end{array}$ & $\begin{array}{l}\mathrm{T} \\
\mathrm{m} \\
\mathrm{n}\end{array}$ & & $\begin{array}{l}\mathrm{N} \\
\mathrm{a} \\
1\end{array}$ & $\begin{array}{l}\mathrm{N} \\
\mathrm{X} \\
\mathrm{n}\end{array}$ & $\begin{array}{l}\mathrm{O} \\
\mathrm{f} \\
\mathrm{x}\end{array}$ & $\begin{array}{l}\mathrm{C} \\
\mathrm{i}\end{array}$ & & & \\
\hline
\end{tabular}




\section{ria \\ (GME \\ H25)}

\section{Aeromo}

\begin{tabular}{|c|c|c|c|c|c|c|c|c|c|c|c|c|c|c|}
\hline $\begin{array}{c}\text { hydro } \\
\text { hila } \\
\text { (GMI }\end{array}$ & 256 & $\begin{array}{c}\text { bla }_{\text {OXA- }} \\
48\end{array}$ & $\begin{array}{l}\mathrm{W} \\
\mathrm{T}\end{array}$ & $\mathrm{C}$ & $\mathrm{C}$ & $\mathrm{F}$ & C & $\begin{array}{l}\mathrm{C} \\
\mathrm{z} \\
\mathrm{d}\end{array}$ & $\mathrm{C}$ & $\begin{array}{l}\mathrm{F} \\
\mathrm{i} \\
\mathrm{x}\end{array}$ & $\begin{array}{l}\mathrm{e} \\
\mathrm{p}\end{array}$ & $\begin{array}{l}\mathrm{M} \\
\mathrm{e} \\
\mathrm{c}\end{array}$ & $\begin{array}{c}\mathrm{I} \\
\mathrm{m} \\
\mathrm{p}\end{array}$ & $\mathrm{E}$ \\
\hline
\end{tabular}

H31)

Aeromo

nas

hydrop

hila

(GME

H32)

Aeromo

nas

hydrop

hila/cav 256

iae

(GME

H34)

Aeromo

nas

hydrop

hila/cav 256

iae

(GME

H35)

Aeromo

nas

hydrop

hila/cav

iae

$\begin{array}{lll}\mathrm{W} & \mathrm{A} & \mathrm{T} \\ \mathrm{T} & \mathrm{m} & \mathrm{i} \\ & \mathrm{p} & \mathrm{c}\end{array}$

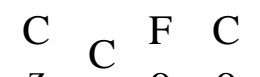

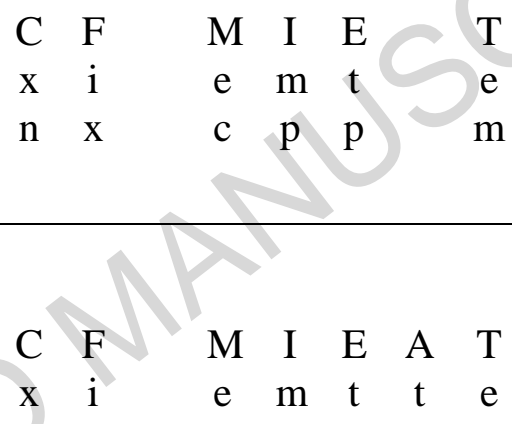

e $m$ t $t$

$\begin{array}{llll}\mathrm{Z} & \mathrm{n} & \mathrm{O} & \mathrm{O} \\ \mathrm{n} & & \mathrm{X} & \mathrm{X}\end{array}$

c $\quad p \quad p \quad m \quad m$

n $x$

$\begin{array}{lccccccccccc}\text { W } & \text { A } & \text { T } & \text { P } & \text { A } & \text { C } & \text { C } & \text { F } & \text { C } & \text { C } & \text { C } & \text { F } \\ \text { T } & \text { m } & \text { i } & \text { t } & \text { m } & \text { z } & \text { n } & \text { o } & \text { o } & \text { z } & \text { x } & \text { i } \\ & \mathrm{p} & \mathrm{c} & \mathrm{z} & \mathrm{c} & \mathrm{n} & & \mathrm{x} & \mathrm{x} & \mathrm{d} & \mathrm{n} & \mathrm{x}\end{array}$

$\mathrm{G}$
$\mathrm{m}$

T N

$\mathrm{m} \quad \mathrm{a}$

$\begin{array}{ccc}\mathrm{C} & \mathrm{Tm} & \mathrm{C} \\ \mathrm{i} & \mathrm{p} / \mathrm{S} & \mathrm{o} \\ \mathrm{p} & \mathrm{tx} & 1\end{array}$

\section{C}


H37)

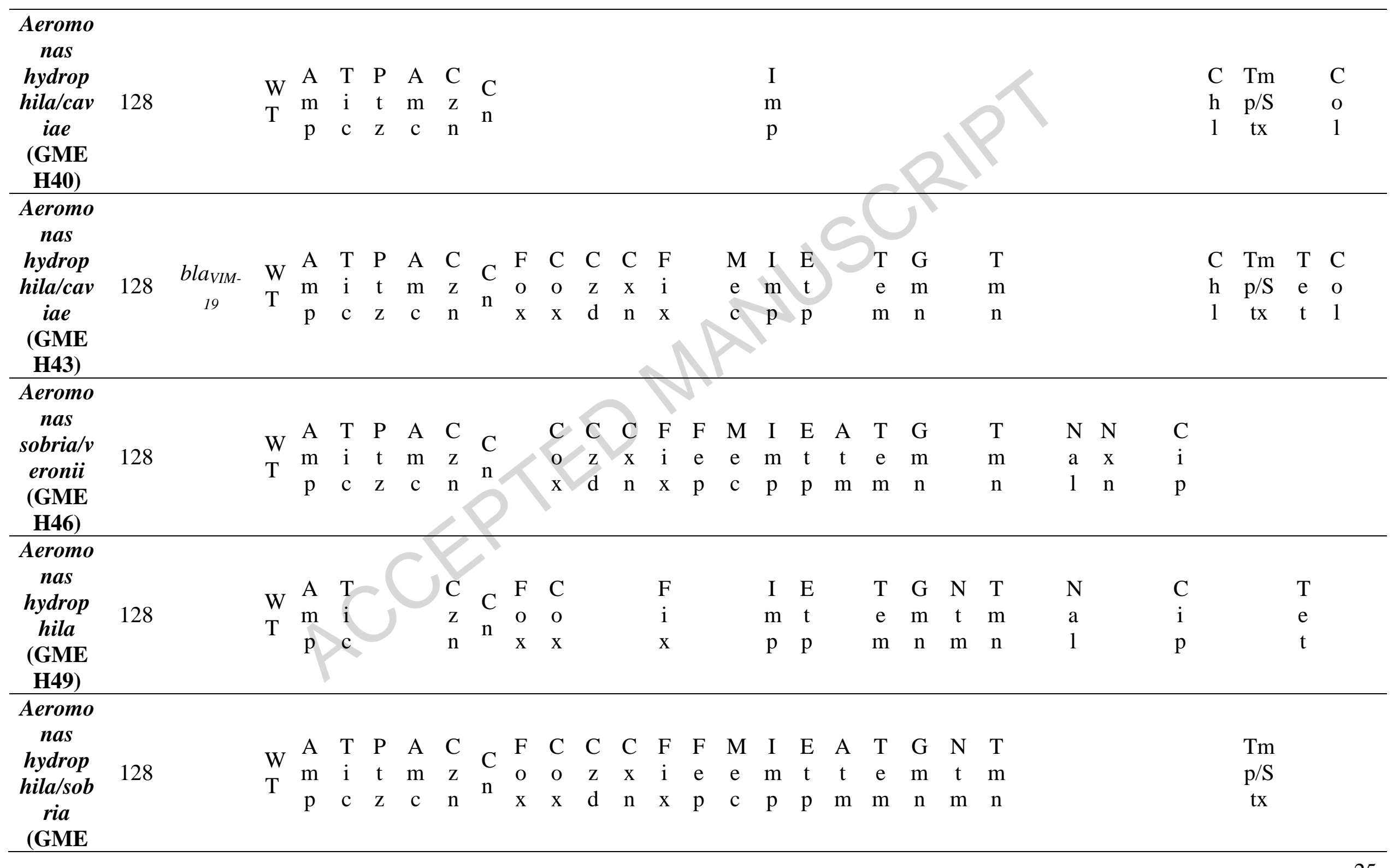




\section{H50)}

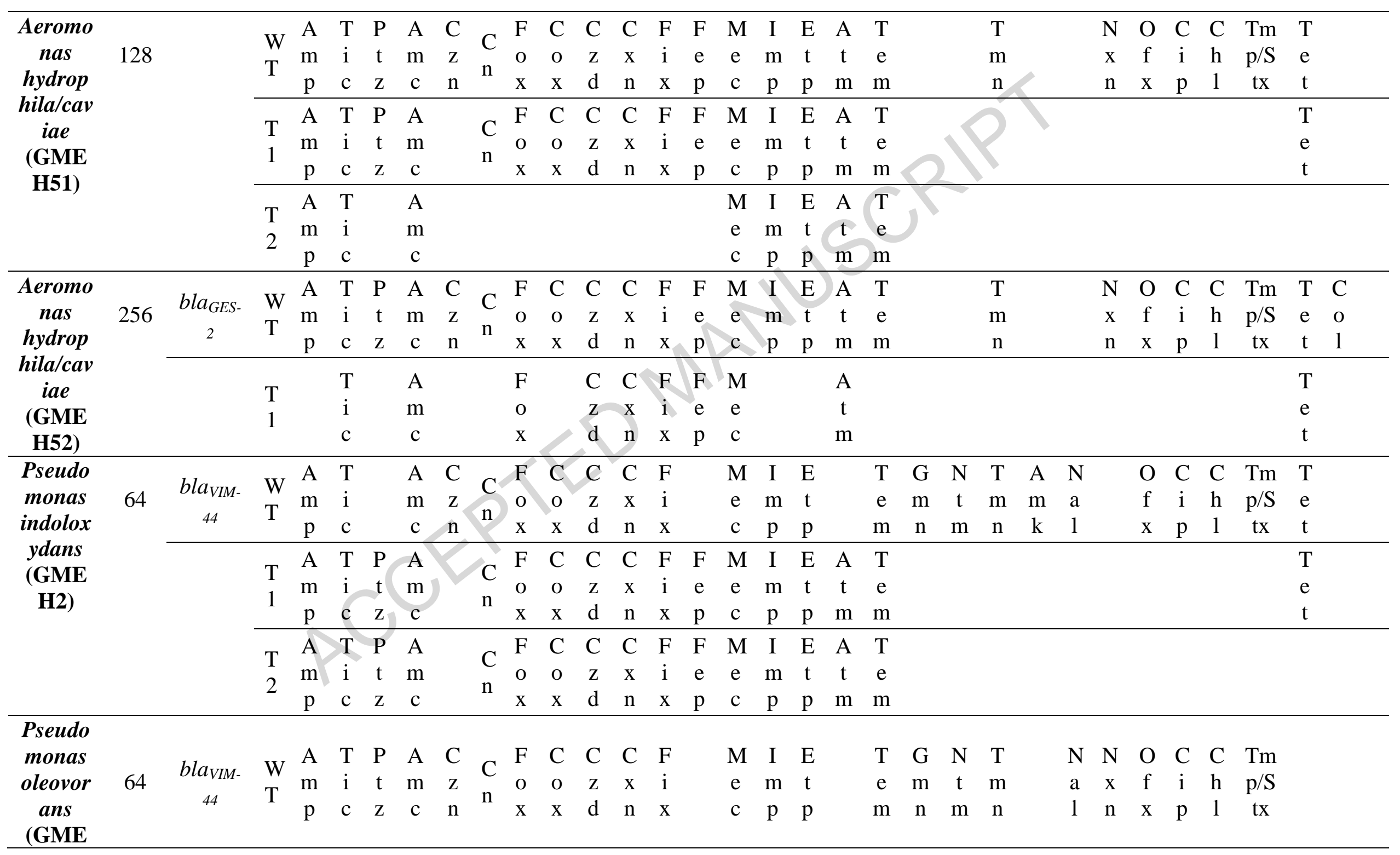


H12)

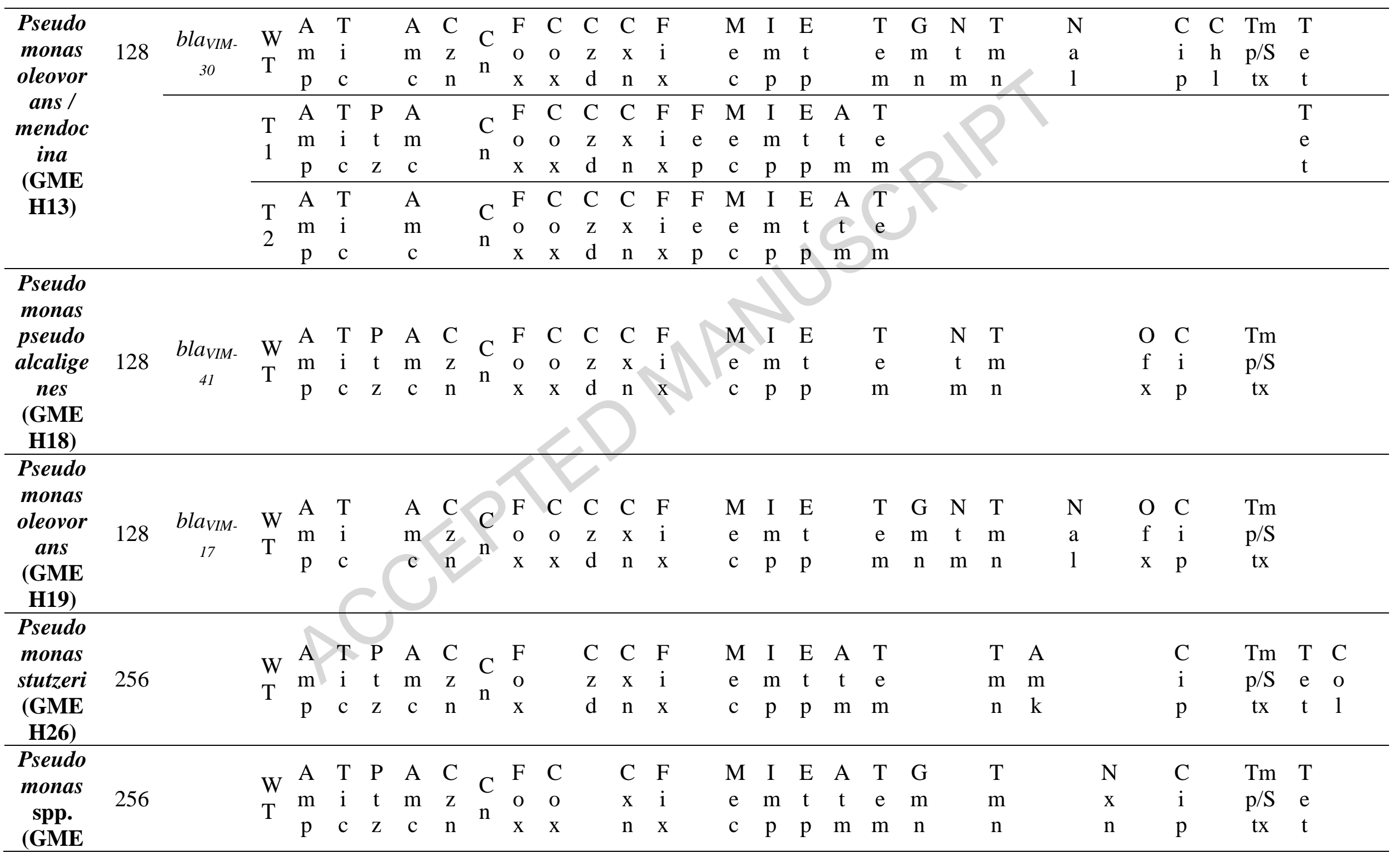


H45)

\begin{tabular}{|c|c|c|c|c|c|c|c|c|c|c|c|c|c|c|c|c|c|c|c|c|c|c|c|c|c|c|c|c|c|c|c|c|}
\hline $\begin{array}{c}\text { Pseudo } \\
\text { monas } \\
\text { oleovor } \\
\text { ans } \\
\text { (GME } \\
\text { H41) }\end{array}$ & 128 & $\begin{array}{cc} & \mathrm{A} \\
\mathrm{W} & \mathrm{m} \\
\mathrm{T} & \mathrm{p}\end{array}$ & $\begin{array}{l}\mathrm{T} \\
\mathrm{i} \\
\mathrm{c}\end{array}$ & $\begin{array}{l}P \\
t \\
z\end{array}$ & $\begin{array}{c}\mathrm{A} \\
\mathrm{m} \\
\mathrm{c}\end{array}$ & $\begin{array}{l}\mathrm{C} \\
\mathrm{z} \\
\mathrm{n}\end{array}$ & $\begin{array}{l}\mathrm{C} \\
\mathrm{n}\end{array}$ & $\begin{array}{l}\mathrm{F} \\
\mathrm{O} \\
\mathrm{X}\end{array}$ & $\begin{array}{l}\mathrm{C} \\
\mathrm{o} \\
\mathrm{X}\end{array}$ & $\begin{array}{l}\mathrm{C} \\
\mathrm{z} \\
\mathrm{d}\end{array}$ & $\begin{array}{l}\mathrm{C} \\
\mathrm{x} \\
\mathrm{n}\end{array}$ & $\begin{array}{l}\mathrm{F} \\
\mathrm{i} \\
\mathrm{x}\end{array}$ & $\begin{array}{l}\mathrm{F} \\
\mathrm{e} \\
\mathrm{p}\end{array}$ & $\begin{array}{l}\mathrm{M} \\
\mathrm{e} \\
\mathrm{c}\end{array}$ & $\begin{array}{l}\mathrm{I} \\
\mathrm{m} \\
\mathrm{p}\end{array}$ & $\begin{array}{l}E \\
t \\
p\end{array}$ & $\begin{array}{l}\mathrm{A} \\
\mathrm{t} \\
\mathrm{m}\end{array}$ & $\begin{array}{l}\mathrm{T} \\
\mathrm{e} \\
\mathrm{m}\end{array}$ & $C$ & & & $\mathrm{~T}$ & & & & $\begin{array}{l}\mathrm{N} \\
\mathrm{X} \\
\mathrm{n}\end{array}$ & $\begin{array}{l}O \\
f \\
x\end{array}$ & $\begin{array}{l}\mathrm{C} \\
\mathrm{i} \\
\mathrm{p}\end{array}$ & $\begin{array}{l}\mathrm{C} \\
\mathrm{h} \\
\mathrm{l}\end{array}$ & $\begin{array}{c}\mathrm{Tm} \\
\mathrm{p} / \mathrm{S} \\
\mathrm{tx}\end{array}$ & $\begin{array}{l}\mathrm{T} \\
\mathrm{e} \\
\mathrm{t}\end{array}$ & $\begin{array}{l}\mathrm{C} \\
\mathrm{O} \\
1\end{array}$ \\
\hline $\begin{array}{c}\text { Pseudo } \\
\text { monas } \\
\text { oleovor } \\
\text { ans } \\
\text { (GME } \\
\text { H42) } \\
\end{array}$ & 64 & $\begin{array}{cc}\mathrm{A} & \mathrm{A} \\
\mathrm{W} & \mathrm{m} \\
\mathrm{T} & \mathrm{p}\end{array}$ & $\begin{array}{l}\mathrm{T} \\
\mathrm{i} \\
\mathrm{c}\end{array}$ & & $\begin{array}{l}\mathrm{A} \\
\mathrm{m} \\
\mathrm{c}\end{array}$ & $\begin{array}{l}\mathrm{C} \\
\mathrm{z} \\
\mathrm{n}\end{array}$ & $\begin{array}{l}\mathrm{C} \\
\mathrm{n}\end{array}$ & $\begin{array}{l}\mathrm{F} \\
\mathrm{O} \\
\mathrm{X}\end{array}$ & $\begin{array}{l}\mathrm{C} \\
\mathrm{O} \\
\mathrm{X}\end{array}$ & $\begin{array}{l}C \\
z \\
d\end{array}$ & $\begin{array}{l}\mathrm{C} \\
\mathrm{x} \\
\mathrm{n}\end{array}$ & $\begin{array}{l}\mathrm{F} \\
\mathrm{i} \\
\mathrm{x}\end{array}$ & & $\begin{array}{l}\mathrm{M} \\
\mathrm{e} \\
\mathrm{c}\end{array}$ & $\begin{array}{l}\mathrm{I} \\
\mathrm{m} \\
\mathrm{p}\end{array}$ & $\begin{array}{l}E \\
t \\
p\end{array}$ & & $\begin{array}{l}\mathrm{T} \\
\mathrm{e} \\
\mathrm{m}\end{array}$ & $\begin{array}{l}n \\
\mathrm{n}\end{array}$ & & n & $\begin{array}{l}\mathrm{T} \\
\mathrm{m} \\
\mathrm{n}\end{array}$ & $\begin{array}{l}\mathrm{m} \\
\mathrm{k}\end{array}$ & & & $\begin{array}{l}N \\
\mathrm{X} \\
\mathrm{n}\end{array}$ & $\begin{array}{l}O \\
f \\
x\end{array}$ & $\begin{array}{l}\mathrm{C} \\
\mathrm{i} \\
\mathrm{p}\end{array}$ & $\begin{array}{l}\mathrm{C} \\
\mathrm{h} \\
1\end{array}$ & $\begin{array}{c}\mathrm{Tm} \\
\mathrm{p} / \mathrm{S} \\
\mathrm{tx}\end{array}$ & $\begin{array}{l}\mathrm{T} \\
\mathrm{e} \\
\mathrm{t}\end{array}$ & \\
\hline $\begin{array}{c}\text { Pseudo } \\
\text { monas } \\
\text { oleovor } \\
\text { ans } \\
\text { (GME } \\
\text { H44) } \\
\end{array}$ & 128 bla $_{V I M}$ & $\begin{array}{cc} & \mathrm{A} \\
\mathrm{W} & \mathrm{m} \\
\mathrm{T} & \mathrm{p}\end{array}$ & $\begin{array}{l}\mathrm{T} \\
\mathrm{i} \\
\mathrm{c}\end{array}$ & $\begin{array}{l}P \\
t \\
z\end{array}$ & & $\begin{array}{l}\mathrm{C} \\
\mathrm{z} \\
\mathrm{n}\end{array}$ & $\begin{array}{l}\mathrm{C} \\
\mathrm{n}\end{array}$ & $\begin{array}{l}\mathrm{F} \\
\mathrm{o} \\
\mathrm{X}\end{array}$ & $\begin{array}{l}\mathrm{C} \\
\mathrm{o}\end{array}$ & $\begin{array}{l}\mathrm{C} \\
\mathrm{z} \\
\mathrm{d}\end{array}$ & $\begin{array}{l}\mathrm{C} \\
\mathrm{x} \\
\mathrm{n}\end{array}$ & $\begin{array}{l}\mathrm{F} \\
\mathrm{i} \\
\mathrm{x}\end{array}$ & $\begin{array}{l}\mathrm{F} \\
\mathrm{e} \\
\mathrm{p}\end{array}$ & $\begin{array}{l}\mathrm{M} \\
\mathrm{e} \\
\mathrm{c}\end{array}$ & $\begin{array}{c}\mathrm{I} \\
\mathrm{m} \\
\mathrm{p}\end{array}$ & $\begin{array}{l}\mathrm{t} \\
\mathrm{p}\end{array}$ & & $\begin{array}{l}\mathrm{T} \\
\mathrm{e} \\
\mathrm{m}\end{array}$ & $C$ & & J & $\begin{array}{l}\mathrm{T} \\
\mathrm{m} \\
\mathrm{n}\end{array}$ & & & & & $\begin{array}{l}\mathrm{O} \\
\mathrm{f} \\
\mathrm{x}\end{array}$ & $\begin{array}{l}\mathrm{C} \\
\mathrm{i} \\
\mathrm{p}\end{array}$ & & $\begin{array}{c}\mathrm{Tm} \\
\mathrm{p} / \mathrm{S} \\
\mathrm{tx}\end{array}$ & & \\
\hline $\begin{array}{c}\text { Stenotr } \\
\text { ophom } \\
\text { onas } \\
\text { maltop } \\
\text { hilia } \\
\text { (GME } \\
\text { H14) } \\
\end{array}$ & 128 & $\begin{array}{cc}\mathrm{W} & \mathrm{A} \\
\mathrm{T} & \mathrm{m} \\
& \mathrm{p}\end{array}$ & $\begin{array}{l}\mathrm{T} \\
\mathrm{i}\end{array}$ & $\begin{array}{l}P \\
t \\
Z\end{array}$ & $\mathrm{~m}$ & $\begin{array}{l}\mathrm{C} \\
\mathrm{z} \\
\mathrm{n}\end{array}$ & $\begin{array}{l}\mathrm{C} \\
\mathrm{n}\end{array}$ & $\begin{array}{l}\mathrm{F} \\
\mathrm{o} \\
\mathrm{X}\end{array}$ & $\begin{array}{l}\mathrm{C} \\
\mathrm{O} \\
\mathrm{X}\end{array}$ & $\begin{array}{l}C \\
z \\
d\end{array}$ & $\begin{array}{l}\mathrm{C} \\
\mathrm{x} \\
\mathrm{n}\end{array}$ & $\begin{array}{l}\mathrm{F} \\
\mathrm{i} \\
\mathrm{x}\end{array}$ & & & $\begin{array}{c}\mathrm{I} \\
\mathrm{m} \\
\mathrm{p}\end{array}$ & $\begin{array}{l}E \\
t \\
p\end{array}$ & & $\begin{array}{l}\mathrm{T} \\
\mathrm{e} \\
\mathrm{m}\end{array}$ & $\begin{array}{l}n \\
\mathrm{n}\end{array}$ & & v & $\begin{array}{l}\mathrm{T} \\
\mathrm{m} \\
\mathrm{n}\end{array}$ & & & & & & $\begin{array}{l}\mathrm{C} \\
\mathrm{i} \\
\mathrm{p}\end{array}$ & & $\begin{array}{c}\mathrm{Tm} \\
\mathrm{p} / \mathrm{S} \\
\mathrm{tx}\end{array}$ & & \\
\hline $\begin{array}{c}\text { Stenotr } \\
\text { ophom } \\
\text { onas } \\
\text { maltop } \\
\text { hilia } \\
\text { (GME } \\
\text { H33) }\end{array}$ & 128 & $\begin{array}{cc} & \mathrm{A} \\
\mathrm{W} & \mathrm{m} \\
\mathrm{T} & \mathrm{p}\end{array}$ & $\begin{array}{l}\mathrm{T} \\
\mathrm{i} \\
\mathrm{c}\end{array}$ & $\begin{array}{l}P \\
t \\
z\end{array}$ & $\begin{array}{c}\mathrm{A} \\
\mathrm{m} \\
\mathrm{c}\end{array}$ & $\begin{array}{l}\mathrm{C} \\
\mathrm{z} \\
\mathrm{n}\end{array}$ & $\begin{array}{l}\mathrm{C} \\
\mathrm{n}\end{array}$ & $\begin{array}{l}\mathrm{F} \\
\mathrm{o} \\
\mathrm{x}\end{array}$ & $\begin{array}{l}\mathrm{C} \\
\mathrm{O} \\
\mathrm{X}\end{array}$ & $\begin{array}{l}C \\
z \\
d\end{array}$ & $\begin{array}{l}\mathrm{C} \\
\mathrm{x} \\
\mathrm{n}\end{array}$ & $\begin{array}{l}\mathrm{F} \\
\mathrm{i} \\
\mathrm{x}\end{array}$ & $\begin{array}{l}\mathrm{F} \\
\mathrm{e} \\
\mathrm{p}\end{array}$ & $\begin{array}{l}\mathrm{M} \\
\mathrm{e} \\
\mathrm{c}\end{array}$ & $\begin{array}{l}\mathrm{I} \\
\mathrm{m} \\
\mathrm{p}\end{array}$ & $\begin{array}{l}E \\
t \\
p\end{array}$ & $\begin{array}{c}A \\
t \\
m\end{array}$ & $\begin{array}{l}\mathrm{T} \\
\mathrm{e} \\
\mathrm{m}\end{array}$ & $\begin{array}{l}C \\
\mathrm{n}\end{array}$ & & & $\begin{array}{l}\mathrm{T} \\
\mathrm{m} \\
\mathrm{n}\end{array}$ & k & & J & $\begin{array}{l}N \\
X \\
n\end{array}$ & $\begin{array}{l}O \\
\mathrm{f} \\
\mathrm{x}\end{array}$ & $\begin{array}{l}\mathrm{C} \\
\mathrm{i} \\
\mathrm{p}\end{array}$ & $\begin{array}{l}\mathrm{C} \\
\mathrm{h} \\
\mathrm{l}\end{array}$ & $\begin{array}{c}\mathrm{Tm} \\
\mathrm{p} / \mathrm{S} \\
\mathrm{tx}\end{array}$ & $\begin{array}{l}\mathrm{T} \\
\mathrm{e} \\
\mathrm{t}\end{array}$ & $\begin{array}{l}\mathrm{C} \\
\mathrm{O} \\
1\end{array}$ \\
\hline
\end{tabular}




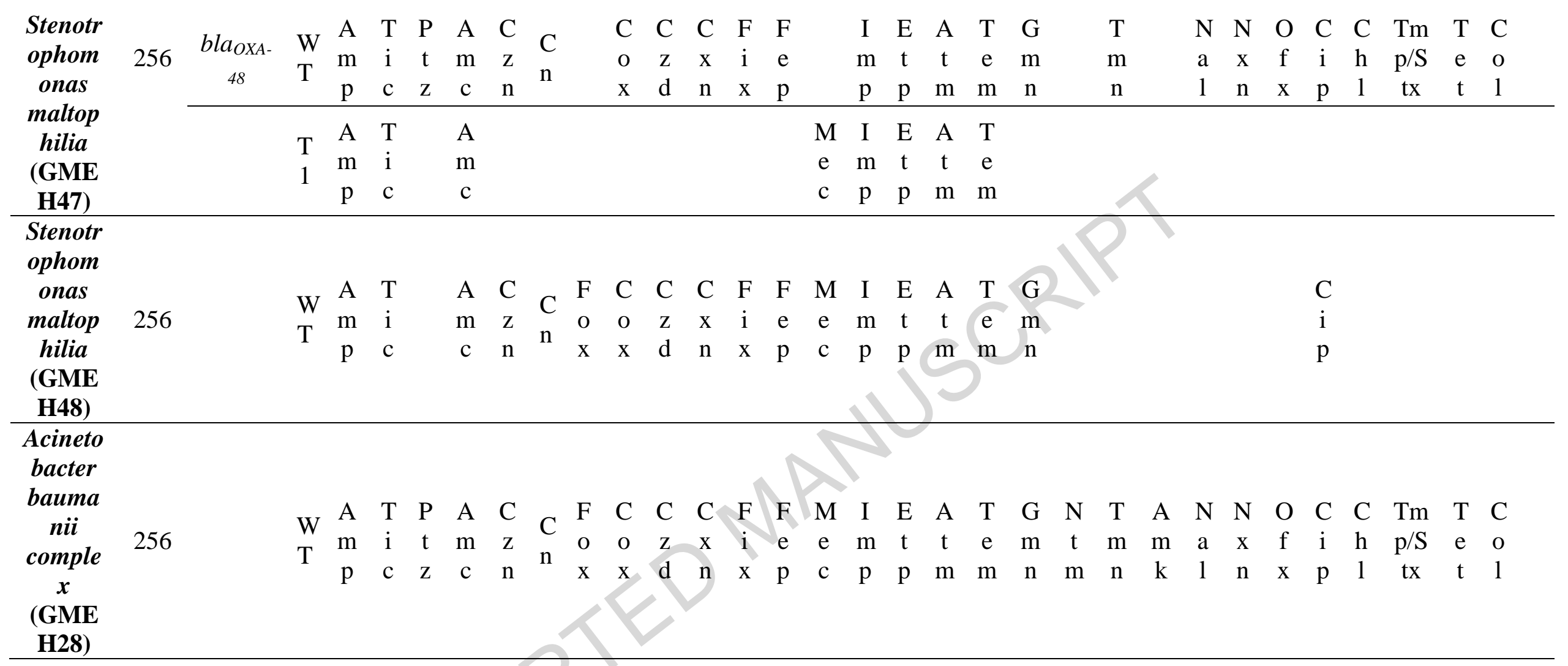

Ampicillin (Amp, $10 \mu \mathrm{g}$ ), ticarcillin (Tic, $75 \mu \mathrm{g}$ ), piperacillin +tazobactam (Ptz, 30/6 $\mu \mathrm{g}$ ), Amoxicillin-clavulanic acid (Amc, 20-10 $\mu \mathrm{g}$ ), cephazolin $(\mathrm{Czn}, 30 \mu \mathrm{g})$, cefalexin $(\mathrm{Cn}, 30 \mu \mathrm{g})$, cefoxitin (Fox, $30 \mu \mathrm{g})$, cefotaxime (Cox, $5 \mu \mathrm{g})$, ceftazidime (Czd, $10 \mu \mathrm{g})$, cefuroxime (Cxn, $30 \mu \mathrm{g})$, cefixime (Fix, $5 \mu \mathrm{g}$ ), cefepime (Fep, $30 \mu \mathrm{g}$ ), mecillinam (Mec, $10 \mu \mathrm{g}$ ), imipenem (Imp, $10 \mu \mathrm{g}$ ), ertapenem (Etp, $10 \mu \mathrm{g})$, aztreonam (Atm, $30 \mu \mathrm{g})$, temocillin (Tem, $30 \mu \mathrm{g})$, gentamicin (Gmn, $10 \mu \mathrm{g})$, netilmicin (Ntm, $10 \mu \mathrm{g})$, tobramycin (Tmn, $10 \mu \mathrm{g})$, amikacin (Amk, $30 \mu \mathrm{g})$, nalidixic acid (Nal, $30 \mu \mathrm{g})$, norfloxacin (Nxn, $10 \mu \mathrm{g}$ ), ofloxacin (Ofx, $5 \mu \mathrm{g}$ ), ciprofloxacin (Cip, $5 \mu \mathrm{g}$ ), chloramphenicol (Chl, $30 \mu \mathrm{g}$ ), trimethoprim and sulfamethoxazole (Stx/Tmp, $25 \mu \mathrm{g})$, tetracycline (Tet,30 $\mu \mathrm{g}$ ), rifampicin (Rif,30 $\mu \mathrm{g}$ ) and colistin (Col, $10 \mu \mathrm{g})$ (Bio-Rad, Ivry-sur-Seine, France) 
Figure 1. Determination of the stability of imipenem using the agar (Müller Hinton, MH) diffusion test and the imipenem-susceptible strain Escherichia coli K12 C600. Agar diffusion tests were performed in triplicate (IMP1, IMP2 and IMP3) by loading imipenem (10 $\mu$ g) stored at $26^{\circ} \mathrm{C}$ for different lengths of time $(\mathrm{T}=0 \mathrm{~h}, \mathrm{~T}=30 \mathrm{~h}$ and $\mathrm{T}=48 \mathrm{~h})$ on paper discs. The negative $(\mathrm{T}-)$ and positive $(\mathrm{T}+)$ controls consisted of paper discs impregnated with saline and commercial imipenem disks $(10 \mu \mathrm{g})$, respectively.

Figure 2. Percentage of imipenem activity determined by measurement of its bactericidal effect on E.coli after different storage times at $26^{\circ} \mathrm{C}(\bullet$ agar diffusion test and $\boldsymbol{\Delta}$ broth medium test) 
T0h

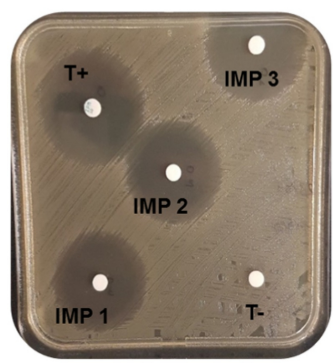

T30h

T48h
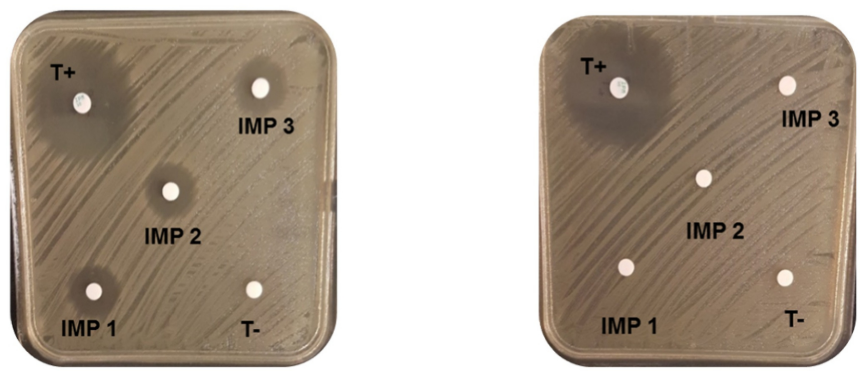

Figure 1 


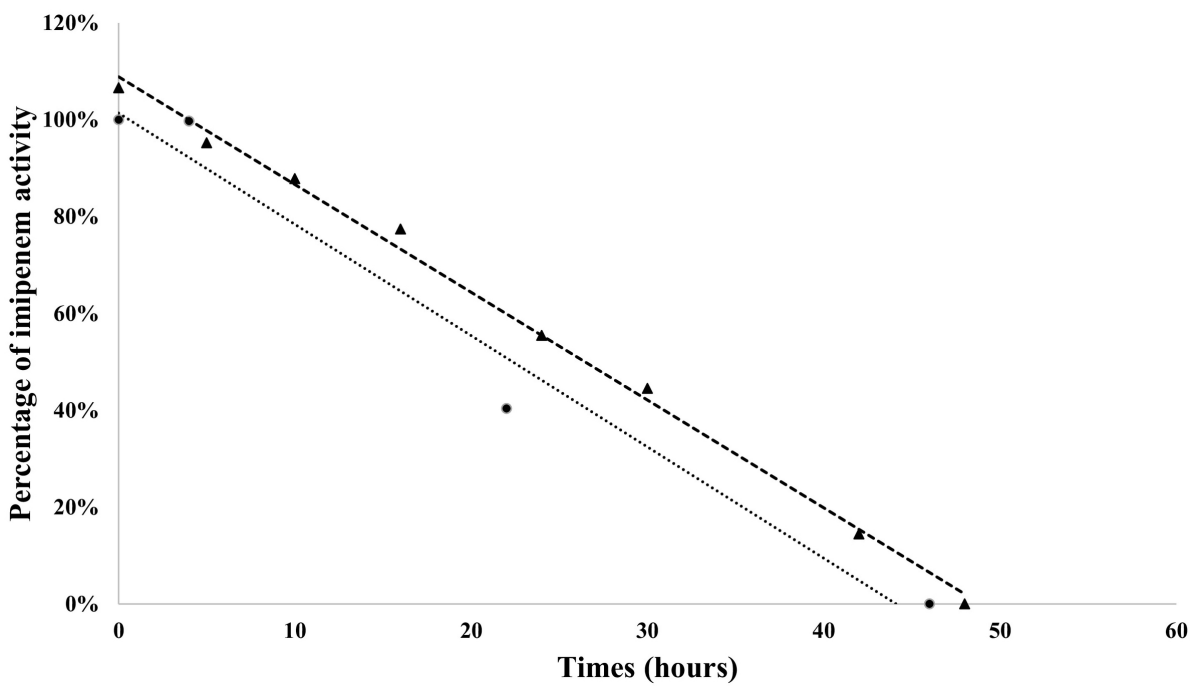

Figure 2 